\title{
Marine Species Introduced on the French Channel-Atlantic Coasts: A Review of Main Biological Invasions and Impacts
}

\author{
Valérie Stiger-Pouvreau, Gérard Thouzeau* \\ UBO-CNRS, Institut Universitaire Européen de la Mer, UMR 6539 (LEMAR), Plouzané, France \\ Email: ${ }^{*}$ gerard.thouzeau@univ-brest.fr
}

Received 15 March 2015; accepted 24 May 2015; published 29 May 2015

Copyright (C) 2015 by authors and Scientific Research Publishing Inc.

This work is licensed under the Creative Commons Attribution International License (CC BY). http://creativecommons.org/licenses/by/4.0/

\section{c) (i) Open Access}

\section{Abstract}

The impacts of anthropogenisation modify permanently the distribution patterns of brackish and marine species. Globalization leads to a rapid increase of the numbers of introduced species anywhere in the world. Biological invasions often result in significant losses in the economic value, biological diversity and function of invaded ecosystems. This review presents the main pathways of introduction of non-indigenous species and the main benthic taxonomic groups being established and/or invasive along the French Channel-Atlantic coasts. A focus is put on main invasive marine species in the intertidal and subtidal zones of Brittany (France), among macroalgae (Sargassum muticum, Grateloupia turuturu, Undaria pinnatifida, Codium fragile and Gracilaria vermiculophylla), halophytes (Spartina alterniflora) and benthic invertebrates (Mollusks: Crepidula fornicata, Crassostrea gigas and Venerupis philippinarum). The species biology, introduction vectors, reproductive and dispersal capacities are considered, together with proliferation patterns along the Channel-Atlantic coasts. The ecological impacts of these species on the environment are also described, as well as the European regulations existing to limit alien species introduction and some examples of struggle against the invaders including eradication trials and biomass valorization. Last, the on-going impacts of global changes on alien species invasiveness along the ChannelAtlantic coasts are discussed.

\section{Keywords}

Invasive Species, French Channel-Atlantic Coasts, Halophyte, Macroalgae, Mollusks, Impacts, Remediation

\footnotetext{
${ }^{*}$ Corresponding author.
}

How to cite this paper: Stiger-Pouvreau, V. and Thouzeau, G. (2015) Marine Species Introduced on the French Channel-Atlantic Coasts: A Review of Main Biological Invasions and Impacts. Open Journal of Ecology, 5, 227-257. 


\section{Introduction}

The geographic distribution of species on the Planet is in constant evolution through increases, decreases or shifting (horizontal/vertical niche movements for "northern" and "southern" taxa) of species distribution areas. The latter are regulated by natural or anthropogenic mechanisms including ecological processes (natural dispersal of species), evolutionary mechanisms, and changes of environmental conditions (climate, hydrodynamics, habitats, food availability, contaminants, etc.). These dynamics contribute creating local and regional biotopes along time and defining biogeographical realms and ecoregions at global scale. WWF defines an ecoregion as a "large unit of land or water containing a geographically distinct assemblage of species, natural communities, and environmental conditions". The boundaries of an ecoregion are not fixed and sharp, but rather encompass an area within which important ecological and evolutionary processes most strongly interact. Several international organizations have defined ecoregions: the Commission for Environmental Cooperation of North America, The European Environment Agency (EEA-DMEER), the National Oceanic and Atmospheric Administration, the World Wildlife Fund, etc. Thus, Brittany (west of France) belongs to the North-Atlantic Temperate realm and comprises two marine ecoregions: the South European Atlantic Shelf and the Celtic seas (http://www.world wildlife.org/science/ecoregions/marine/ecoregion_area3.html). These two ecoregions are separated by the Ushant thermal front off northwestern France, which acts for ages as a genuine geographical barrier.

The impacts of anthropogenisation modify permanently the distribution patterns of brackish and marine species. Increasing shipping, aquaculture of mollusks, fish and macroalgae species (including species introduced from Asia and North America), rise of aquarium trade and Lessepsian (Erythrean) migrations have led to increasing introductions of non-indigenous species in the different ecoregions. In the Mediterranean Sea, the majority of alien species entered through the Suez Canal (53\%) and an additional 11\% were introduced primarily through the Canal and then dispersed by vessels [1]. At global scale, at least one alien species would be invasive in $84 \%$ of the 232 marine ecoregions [2]. The first introductions are ancient; thus, the steamer clam, Mya arenaria (Mollusca Bivalvia), would have been introduced in Europe by the Viking ships coming back from America [3]. Globalization leads to a rapid increase of the numbers of introduced species and, subsequently, of the numbers of invasive species. Along the European Atlantic coasts, $50 \%$ of introductions of marine plants and algae occurred after 1960 [3].

Once introduced, these non-indigenous species can settle and be invasive in some cases. It is now possible to get a comprehensive overview of which alien species are present in Europe, their impacts and consequences for the environment and society. More than 11,000 alien species have been documented by DAISIE (Delivering Alien Invasive Species Inventory for Europe), a unique three year research project with more than 100 European scientists, funded by the European Union that provides new knowledge on biological invasions in Europe. Biological invasions by alien species often result in significant losses in the economic value, biological diversity and function of invaded ecosystems [4]. The majority of these 11,000 alien species are however, not harmful. About $15 \%$ of these alien species would cause economic damages and $15 \%$ would cause harm to biological diversity that is the environment, habitats and native plants, animals and micro-organisms, according to the DAISIE "Handbook on alien species in Europe" [5] (see also www.europe-aliens.org). Species-specific review of the impacts of invasive alien marine species on ecosystem services and biodiversity in the European Seas has been published recently [4].

\section{Definitions}

\subsection{Introduced Species}

A given species is considered being introduced if it matches four criteria [6]: 1) the species is non-native to the ecosystem under consideration; 2) its occurrence and development are directly or indirectly linked to anthropogenic activities; 3) its dispersal has created a geographic discontinuity between its original distribution area and the colonized area; and 4) there is no need of man intervention to give birth to new generations of this species. Thus, the latter is going to reproduce naturally and constitute self-sufficient populations allowing sustainable settlement. Ultimately, this species will become a naturalized species.

Introductions of alien species are said "primary" when the species are identified for the first time in a given area that would be the French Atlantic-Channel coasts in this study. Introductions are "secondary" when they come from introduction centers located elsewhere on the European coasts with a secondary transfer on the 
French coasts.

\subsection{Invasive Species}

According to the IUCN (http://www.iucn.org) definition, "invasive alien species are animals, plants or other organisms introduced by man into places out of their natural range of distribution, where they become established and disperse, generating a negative impact on the local ecosystem and species". Negative impacts encompass economic (on fisheries, aquaculture, tourism, etc.) or environmental (on native species biodiversity, habitats, biogeochemical cycles, etc.) harm or harm to human health (e.g. toxic harmful algae blooms).

The understanding of invasiveness (i.e. the ability of species to establish in, spread to or become abundant in novel communities) and invasibility (i.e. the susceptibility of habitats to the establishment or proliferation of invaders; [7]) requires solving two evolutionary paradoxes: 1) why does a non-native species succeed in establishing in and spreading to an ecosystem for which it is not adapted in theory, sometimes outcompeting native species; and 2), why do invasive populations succeed so rapidly in adapting to their new environment.

\subsection{The Keys to Introduction Success}

The factors leading to the success or failure of the establishment of non-native populations are multiple and often difficult to determine or rank. Success likelihood is often defined from the propagule pressure that is a composite measure of the number of individuals released into a region to which they are not native [8]. It incorporates estimates of the absolute number of individuals involved in any one release event (propagule size) and the number of discrete release events (propagule number). As the number of releases and/or the number of individuals released increases, propagule pressure also increases [9]. This pressure, which also takes the potential existence of introduction hot spots into account, is generally high in coastal marine environment, partly due to the vectors of introduction being involved. Introduction success will depend on the ability of the alien species to overcome various "barriers" to and within its new environment, with several demographic, ecological and evolutionary mechanisms being involved at each step.

1) Geographical barrier: to cross it, the population collected in its native environment must survive transport. The intentional or accidental introductions of species via transoceanic transfers, even from one ocean to the other, bypass the natural dispersal processes. The species is said introduced.

2) Ecological barrier: various biotic and abiotic factors can weaken the introduced population. On another hand, exotic species in their new environment are free from their native enemies, like predators and parasites: this is the enemy release hypothesis [10] [11], which seems not to be always fully convincing [12]. The relations developed by the nonindigenous species with its new environment are then crucial for its survival. The species becomes acclimatized.

3) Reproduction barrier: the latter is limited, amongst others, by the depression of consanguinity, high in small-sized populations. Population adaptation to its new environment, which improves the capacities of survival and reproduction, would play a key role in numerous cases. The species is naturalized.

4) Dispersal barrier: a species able to cross this barrier and to establish new populations in varied biotopes will have chances to proliferate. The dispersal competence of a species will partly determine its invasion potential. The species phenotypic plasticity (local adaptations for reproduction, growth, etc.) promotes also the geographical expansion of introduced populations.

When a species is in the process of naturalization, the population size in its new environment will fluctuate with time, both during the expansion and persistence phases [13].

\subsection{Introduction Mechanisms}

The relative importance (\%) of the main pathways of introduction of non-indigenous species (NIS) across regional seas of Europe in 2014 is shown on Figure 1 (http://www.eea.europa.eu/data-and-maps/figures/mode-ofintroduction-of-nis). Marked geographic patterns depending on the pathway of introduction have been shown, with specific countries acting as gateways to alien invasions [14]. France and Italy would be the countries mostly responsible for introductions by aquaculture, while Lessepsian species were first reported in the countries of the Levantine Sea, especially Israel. Shipping is the most important pathway of introduction in European Seas 

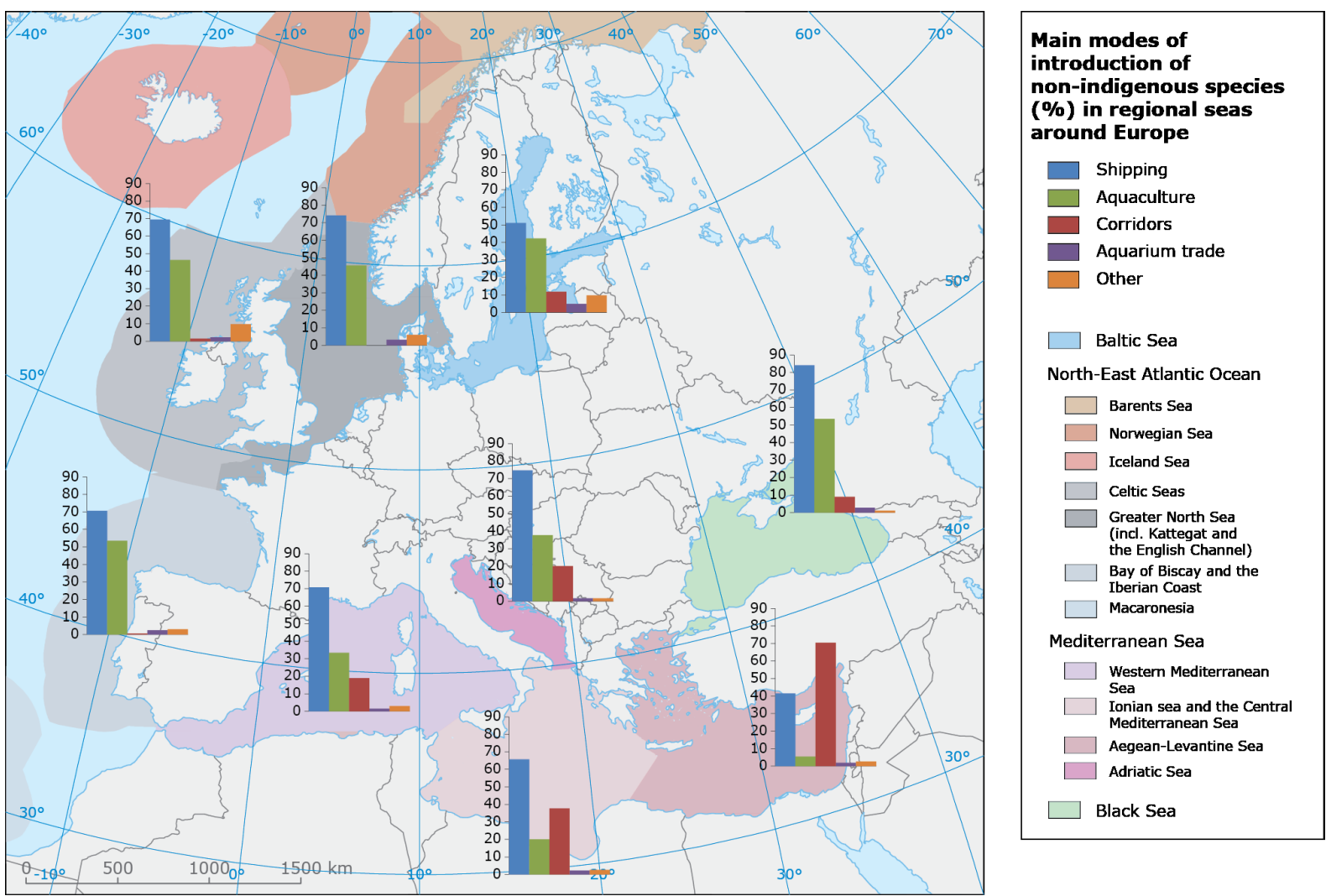

Figure 1. Relative importance (\%) of the main pathways of introduction of non-indigenous species (NIS) across regional seas of Europe in 2014. Main pathways of introduction on the French Atlantic coasts are shipping and aquaculture. In many cases, it is impossible to identify the introduction pathway. Where more than one pathway of introduction can be attributed, the analysis has considered both modes of introduction. Thus the resulting percentage of introductions per pathway amounts to more than 100\%. Data from the European Environment Agency (http://www.eea.europa.eu).

[14]. In particular, numerous species take invasion corridors superimposed to the maritime shipping ways, including the one extending between the North-West Atlantic and British waters [15]. Along the Channel-Atlantic coasts, at least 104 non-indigenous marine or brackish species have been introduced [16]. The voluntary introductions resulting from aquaculture (macroalgae, fishes, mollusks: 13 species listed in 2002) have to be distinguished from the accidental introductions, via oyster spat transfers (25 species would have hitch-hike on oyster shells), the ballast water of ships and boat hull fouling (38 introduced species by maritime ways). One counts also 4 species of parasites introduced with other cultivated species (mussels or eels) and 11 species (at the time of the census of 2002) for which the modes of introduction are unknown.

Today, it is advisable to add to these mechanisms of introduction those related to climate warming and changes, not always perceptible, of the main oceanic currents. Thus, fish species living in waters normally warmer than Breton waters (triggerfish, seabreams, salema, bogue) are more and more regularly observed at the tip of Brittany. Some of them undoubtedly constitute self-recruiting populations today, in particular among the demersal species (the seabream hot spots of the spearfishing divers on the Finistère north coast are an edifying example), whereas it is more difficult to find clear trends for pelagic fishes with great migration capacity [17]. The first seabreams (Diplodus sargus and D. annularis) were fished at the tip of Morgat in the Eighties. Some specimens of salemas (Sarpa salpa) and bogues (Boops boops) were first captured in the trawls of the UBO (Université de Bretagne Occidentale) scientists about 25 years ago in Douarnenez Bay, but it seems that the fish shoals are increasingly dense over the years. It does not seem however that one or more of these alien species became invasive along the Breton coasts. On another hand, Sardina pilchardus tends to disappear in the English Channel; the reasons why remain to be determined. Major impacts of climate change on fish species distribution have been also observed in Aquitaine and Gulf of Biscay waters [18]. 


\section{Inventory along the Channel-Atlantic Coasts}

In the year 2002, 104 species were listed as introduced in the wild on the French Channel-Atlantic coasts since the beginning of the 20th century [16], including 2 protists, 8 phytoplankton species, 21 macroalgae, 4 top plants, 68 invertebrates (including 22 mollusks) and 1 vertebrate (fish). Thus, invertebrates constitute the majority of introduced species, followed by macroalgae.

Most of these introduced species are native of the Pacific (59\%), followed by the East coast of the USA (16\%), the Mediterranean sea (7\%), the North-East Atlantic (5\%), the Indian-Pacific zone (5\%), the South-West Atlantic (2\%), the Indian ocean (2\%), etc. Invasion rate strongly increased from the 60s on (Figure 2), mainly because of increasing shipping and aquaculture. It is thus not surprising that the main zones of introduction are localized between the Normandy coasts and the Arcachon Basin that is the main seashell production sites of the Channel-Atlantic coasts.

These introductions were most abundant in the 70s and still significant in the 90s, in spite of the setting up of French and European legislations limiting the introductions of exotic species. The situation did not improve in the years 2000 since a new census carried out in 2006 led to the enumeration of 153 introduced species (of which ten were invasive), that is to say 12 new species per year on average on the Channel-Atlantic coasts [3].

\section{Main Invasive Species in Brittany}

On the 104 marine species introduced on the Channel-Atlantic coasts in 2002, 70 were established, i.e. settled, reproducing, and thus constituting perennial populations, whereas 20 species had an unpredictable status. Only 14 species seemed not to have succeeded in establishing, thus highlighting the fact that non-native species tend overall to colonize their areas of introduction. Today, about thirty introduced species can be considered as invasive along the Breton coasts (http://www.bretagne-environnement.org/especes-invasives/).

\subsection{Macroalgae}

France constitutes the European country most colonized by introduced species of macroalgae, with 22 species first found on the French coasts (against 9 for England and 6 for Italy) [16].

The top 5 invasive species of macroalgae in Europe comprise, in order of importance, Codium fragile, Caulerpa taxifolia, Undaria pinnatifida, Asparagopsis armata and Grateloupia turuturu [19]: all these species are present in Brittany and are considered for the moment as potentially invasive. Among the species of macroalgae

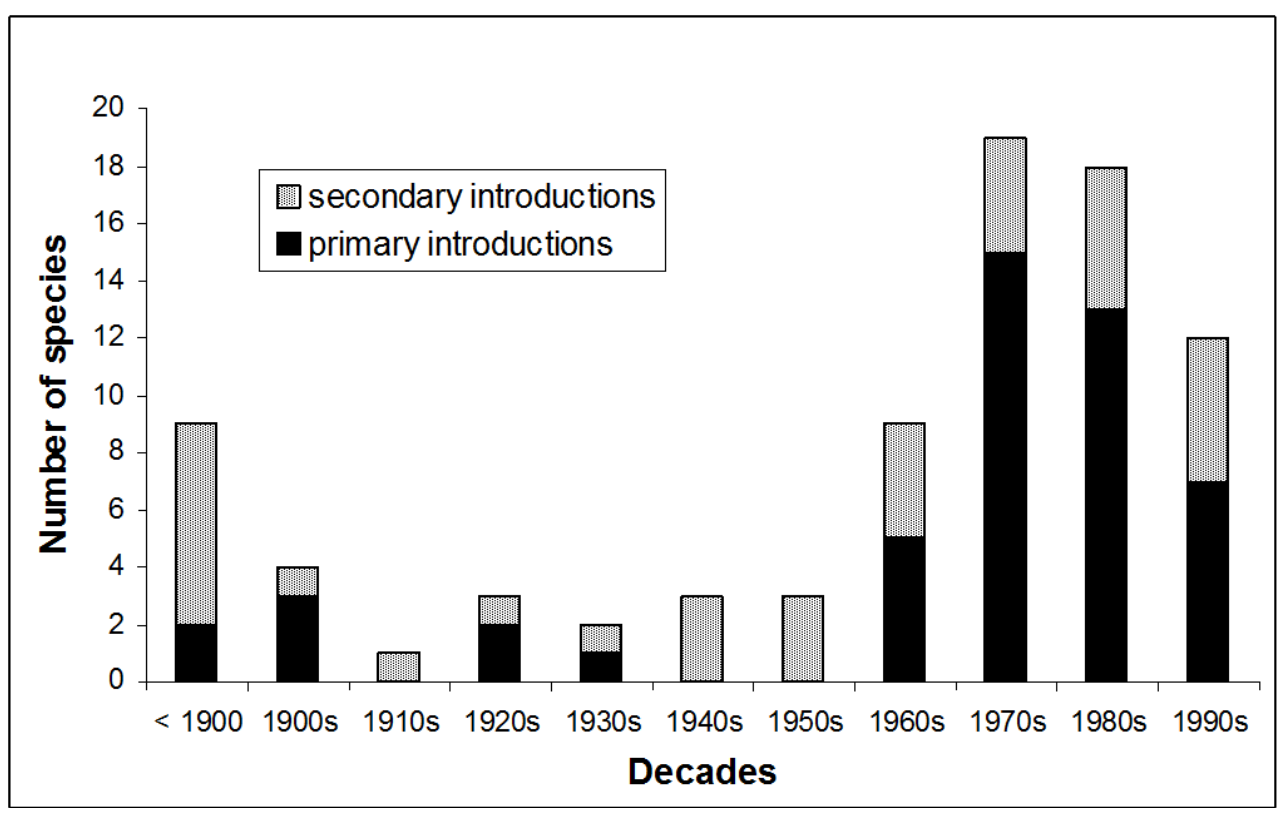

Figure 2. Numbers of records per decades of new non-indigenous species on the French and Spanish Channel-Atlantic coasts (in [16]). 
introduced in Brittany, Grateloupia turuturu, Codium fragile and Undaria pinnatifida are particularly interesting to be studied like models of biological invasion. Even if it does not belong to the top 5 of the invasive species of macroalgae in Europe, Sargassum muticum is the invasive species most studied in Europe, with Caulerpa taxifolia, in order to understand its proliferation, how to eradicate it (especially in the Mediterranean Sea) and how to exploit it. Still nowadays, this species concentrates a lot of attention because of its large distribution in Europe, its settlement in Northern countries (Ireland, Norway) and recently in the north of Morocco, together with nuisances caused by its growth in rock pools in summertime.

Sargassum muticum is a brown macroalga belonging to the order of Fucales. It is native of Japan and was introduced in France via the transfers of the Pacific oyster (Crassostrea gigas), with two centres of introduction (Figure 3(A)): a first one in the Eastern part of the Channel (end of the 60s) and a second one in the Thau lagoon (1980). In less than 30 years, it colonized rocky shores all along the Atlantic coasts: its distribution extends now from Norway to Portugal and to the Adriatic Sea. At the beginning of the introduction process, there were tests of eradication in England and France, mechanical tests primarily, which all failed. This alga, strongly established on the Channel-Atlantic coasts, is regarded henceforth as belonging now to the marine local flora. It is a pseudo-perennial alga, which is very discrete from November to February but which presents strong biomasses during the summertime. The individuals can reach important sizes and, as a consequence, a massive filling by laterals of the surface of the rock pools in summer (Figure 3(B)). Only one generation is present during the development cycle of this alga: it is the diploid meiosporophyte which produces gametes. Sargassum muticum is
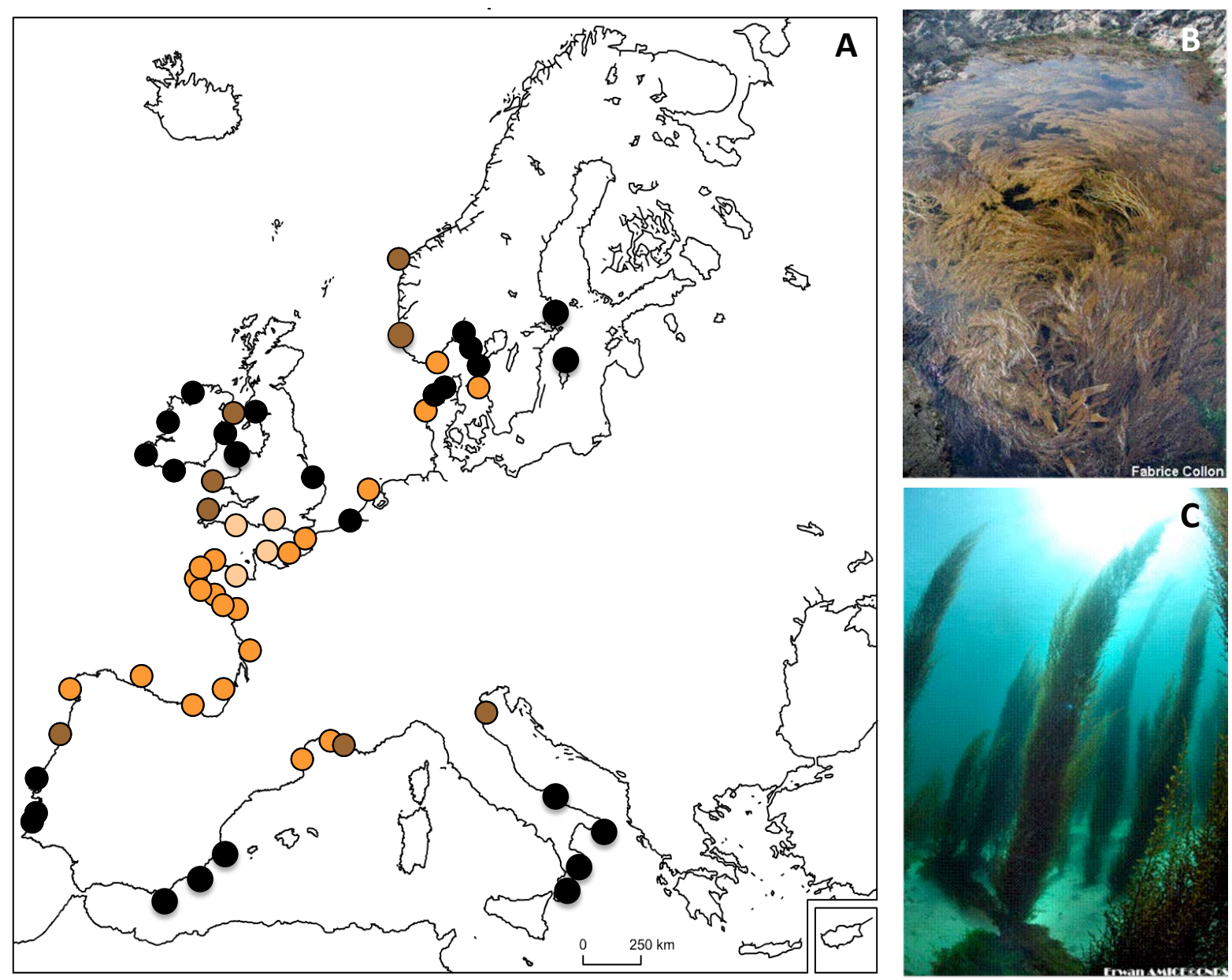

Figure 3. (A) Main sites (hot spots) of introduction and proliferation of Sargassum muticum in Europe (beige: 1973-1980; orange: 1981-1990; brown: 1991-2000; black: 2001 to today) modified according to the DAISIE (Delivering Alien Invasive Species Inventories for Europe) project (http://www.europe-aliens.org). (B) Colonization of intertidal rock pools in summer. (C) Colonization of subtidal areas. 
able to proliferate by marginal dispersal (release of the zygotes) and dispersal by jump (floating fragments of thalli, aquaculture, fouling, etc.). S. muticum occupies all the rock pools in the intertidal zone and also forms populations in subtidal zones (Figure 3(C)) along the French littoral. Most recent works on this species were addressing ecological and ecophysiological processes [20]-[23]. On-going research is turned towards the comprehension of the mechanisms of species dispersal and recruitment, together with a potential valorisation of the biomass by the search for bioactive molecules (see paragraph 7.2.).

Grateloupia turuturu is a red macroalga belonging to the order of Halymeniales. It is also originating from the Pacific and was also introduced in France via transfers of the Pacific oyster, with two ways of introduction like Sargassum muticum. G. turuturu has an important polymorphism; according to the colonized environment, the thallus is represented by a foliaceous blade, which can be either single or divided (Figure 4(A)). This alga, also originating from Japan, was present in Thau lagoon by 1982. It is a large-sized macroalga, described for the moment like the tallest red alga since an individual of $3 \mathrm{~m}$ long was measured on the Callot Island, close to Carantec, in 1999 [24]. On the coasts of Brittany, the species was first described at Fort Bloqué, on the commune of Ploemeur close to Lorient in 1989, and in the second time in the area of Carantec, in the Callot Island, in 1992. Both sites present an important oyster aquaculture activity. G. turuturu then dispersed in a marginal way (liberation of spores), and by jumps, until currently occupying the rock points of north-Cotentin to the Vendée (Figure 4(B)). This species, today very discrete in the colonized area, expects perhaps only one variation of one or several environmental parameters to become invasive. Ecological and biochemical studies were undertaken on Grateloupia turuturu recently [21] [24]. Populations are constituted of a mix of gametophytes and tetrasporophytes and densities vary all year long. G. turuturu is a euryhaline species, producing osmolytes, like floridoside or isethionic acid, for its osmoregulation [24]. On-going studies address the mechanisms of dispersal and osmoregulation of the species and potential valorisation of its biomass by the search of bioactive molecules.

Native of Asia, Undaria pinnatifida, also known under the name of "wakame", is a brown macroalga, which belongs to the order of the Laminariales and measures ca. 1 to $2 \mathrm{~m}$ long (Figure 5(A)). It is a species which faced a world expansion since the years 1970 (Figure 5(B)). It was introduced via the aquaculture but several ways of introduction would be at the origin of the populations observed in Brittany [25]-[27]. In Europe, it is a species colonizing three types of biotopes: aquaculture zones, rockyshores (spontaneous populations) and artificial structures (wharfs, dykes, etc.). Undaria pinnatifida is an alga of cold moderate water which colonizes the higher level of the subtidal zone, generally in areas characterized by strong tidal currents but not beaten [28] [29]. According to the turbidity of the colonized zone, it can settle deeper in the subtidal zone, down to $15 \mathrm{~m}$ depth. Undaria pinnatifida is an annual species presenting a sexual reproductive cycle characterized by an alternation of haploid (gametophytes) and diploid (sporophytes) stages. The sporophytes are the macroscopic phase of the cycle whereas the gametophytic stage is microscopic.

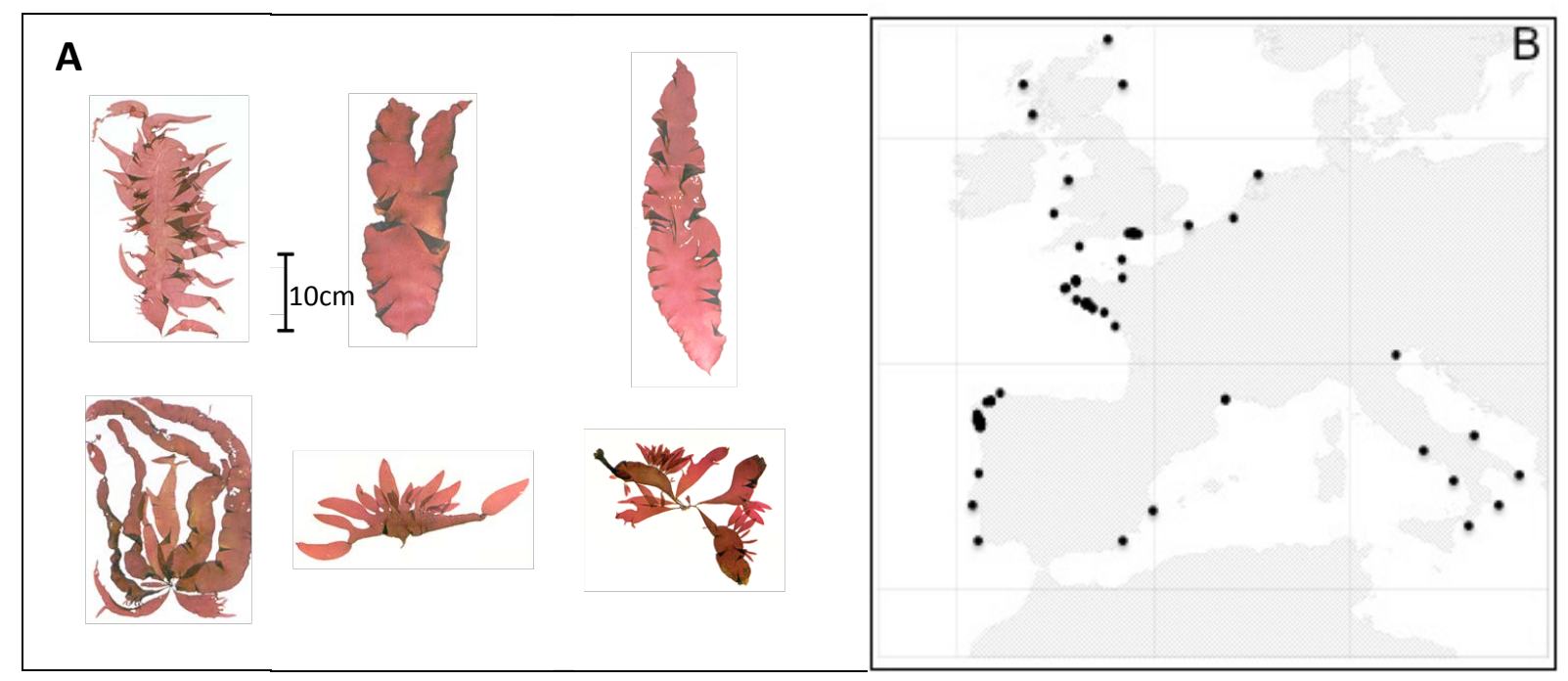

Figure 4. (A) Illustration of Grateloupia turuturu polymorphism according to the colonized environment: the foliaceousblade can be either single or divided [24]. (B) Main sites (hot spots) of introduction of G. turuturu in Europe modified according to the DAISIE project (http://www.europe-aliens.org). 


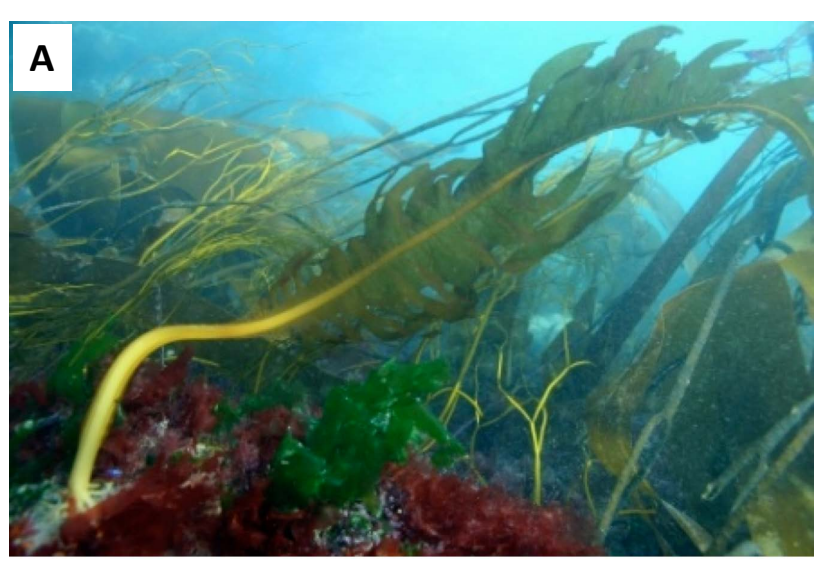

(C) Yann Fontana

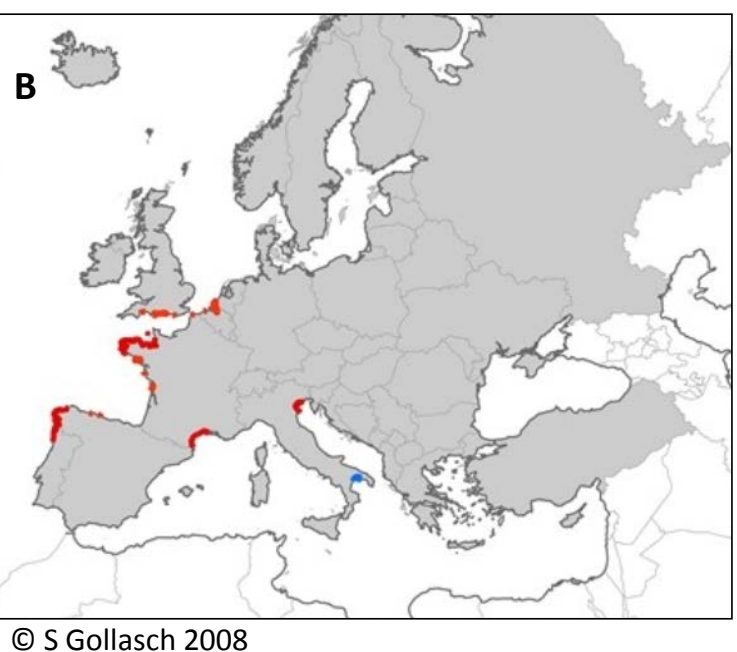

Figure 5. (A) Thallus of Undaria pinnatifida on rocky shore. (B) Distribution according to the DAISIE project (http://www.europe-aliens.org).

Codium fragile is a green macroalga of dark green color presenting a spongy morphology and axes which divide by dichotomy (Figure 6). From a taxonomic point of view, it belongs to the order of Bryopsidales. It is a species which dangerously proliferated at last century between various oceans but also between the two hemispheres [30]. Regarded as native of Japan, it appeared for the first time on European coasts in the Netherlands in the 1900s and then dispersed very quickly in Europe and colonized also the Mediterranean Sea [30]. Codium fragile is a shade-loving species, which lives in the intertidal and subtidal zones on rocky shores all year long (perennial species). The dispersal of $C$. fragile is made in a marginal way (emission of gametes, asexual reproduction by fragmentation) and by jumps (yachting, aquaculture, packaging of products for fish shop, floating of fragments of thalli...). A combination of both types of dispersal is at the origin of its fast proliferation in Europe.

Gracilaria vermiculophylla is a red macroalga (order of Gracilariales), which can form more or less dense carpets in the intertidal zone of muddy shores and upper sublittoral zone, where it attaches to rocks or pebbles. It was originally described in Japan in 1956 as Gracilariopsis vermiculophylla. It is thought to be native of and widespread throughout the Northwest Pacific Ocean. It has been introduced to the East Pacific, the West Atlantic and the East Atlantic, where it rapidly colonized new environments. Now, its distribution range in the North-East Atlantic Ocean extends from Portugal to Norway. It can become very abundant in estuarine areas, like in some streams from the Bay of Brest (Figure 7). G. vermiculophylla consists of a basal disc and a 4to-50-cm-long main axis with cylindrical alternate ramifications also ramified and flexible. It was identified in 1996 in the estuary of Belon and in 2002 in the Wadden Sea [31] [32].

At present, several invasive marine species of macroalgae in Europe, including S. muticum, C. fragile and G. vermiculophylla, are investigated from an ecological point of view within the framework of an ERA-NET Seasera and ANR project entitled "Invasive seaweeds in rising temperatures: impacts and risk assessments (INVASIVES)". This project aims to study the becoming of invasive species in relation with an increase of the seawater temperature in the North Atlantic Ocean and to do predictions in regard of their potential development on the Atlantic coasts.

\subsection{Marine Plants (Halophytes)}

The smooth cordgrass, Spartina alterniflora, is a perennial salt-tolerant herbaceous that grows in dense stands along shorelines. It belongs to the order of Poales and to the family of Poaceae. It is native of the East coast of North America and was introduced on the Western European coasts and North-West American coast. In Europe, S. alterniflora was accidentally introduced during the 19th Century in Western France and Southern England (Figure 7). In France, S. alterniflora was introduced in Brittany in the Bay of Brest (Elorn Estuary), and in the Basque region near Hendaye (Bidassoa Estuary) [33]. S. alterniflora is a plant of the intertidal zone, where it colonizes mud or sandflats in marine or brackish water. In Brittany, S. alterniflora colonizes the shores as well 


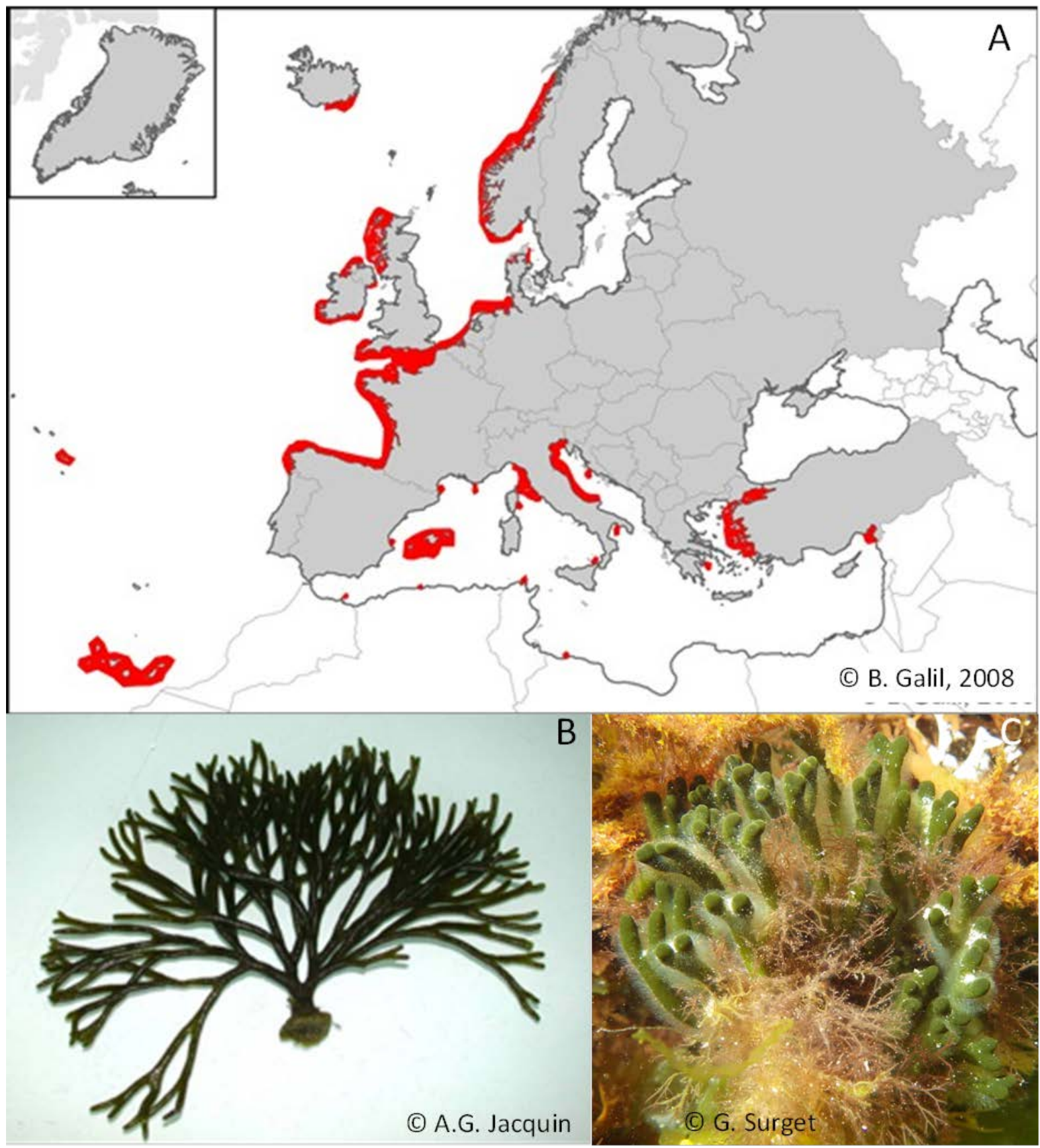

Figure 6. (A) Distribution area of Codium fragile in 2008 (modified from B. Galil). (B) and (C) Codium morphology with axes which divide by dichotomy.

as the top of the saltmarshes (Figure 8). The inflorescence is a flowering panicle made of many spikes and it is 10 - $40 \mathrm{~cm}$ long with dense colorless flowers, which are closely appressed and overlapping. Its alternate 2-D leaf blades, which are grey-green in color, measure from 60 to $120 \mathrm{~cm}$ length. This plant spreads rapidly by fragmentation of its rhizome. It forms monospecific dense meadows, characterized by clonal populations. This species exhibits high tolerance to many ecological factors, in particular tidal submersion. S. alterniflora is in competition with annual native species like Salicornia [34]. In regions where S. alterniflora was introduced, it has hybridized with indigenous species. A sterile hybrid between S. alterniflora and S. maritima was discovered in 1892 in the South-West of France in the Bidassoa estuary [35]. S. alterniflora is at the origin of another invasive species, S. anglica. Indeed, in England, its hybridization with the native S. maritima gave rise to S. $\times$ townsendii, 


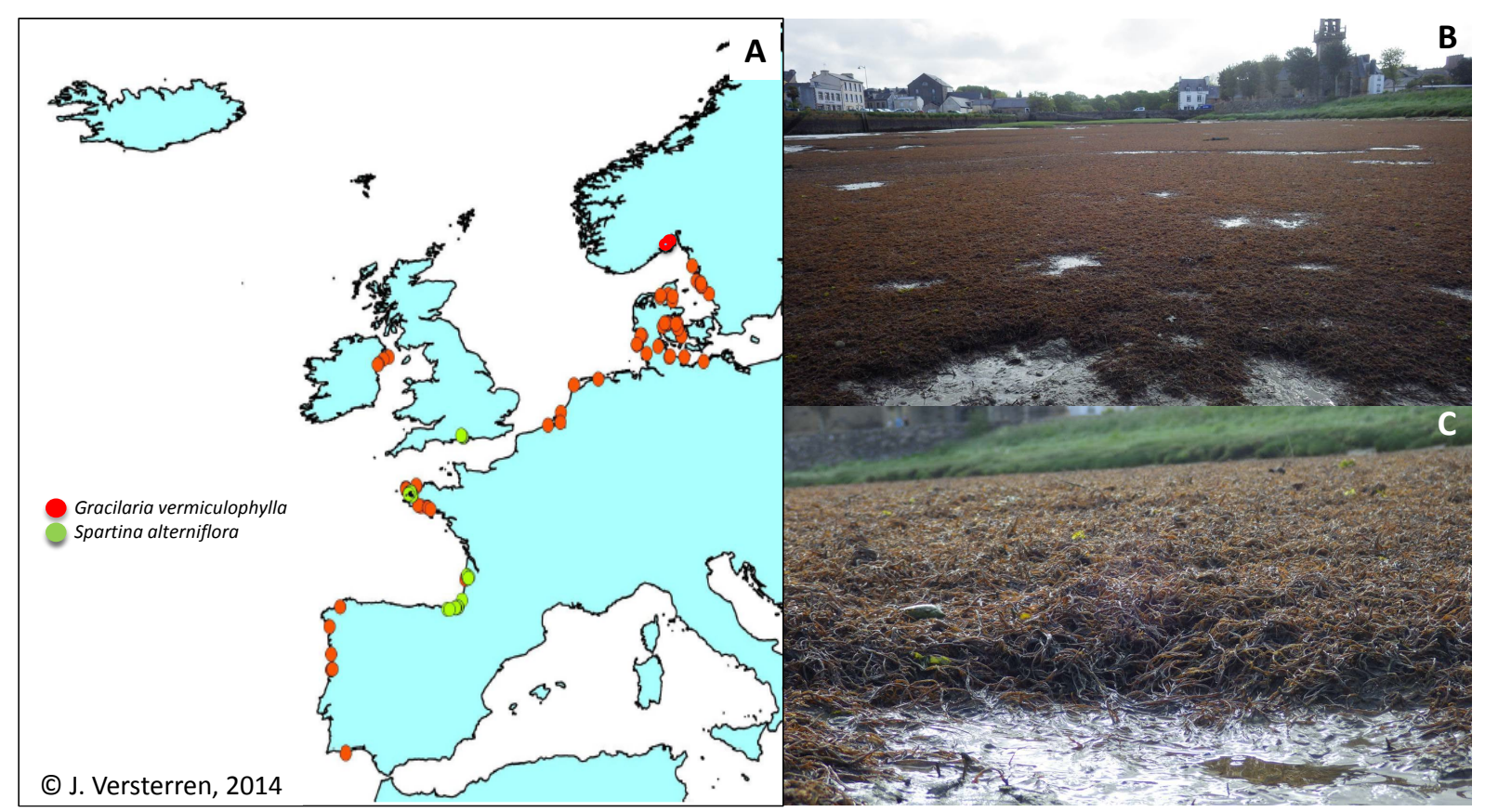

Figure 7. (A) Distribution areas of Gracilaria vermiculophylla and Spartina alterniflora. (B) and (C) Views of Gracilaria vermiculophylla mats at low tide on intertidal mudflats (Photographies from G. Surget).

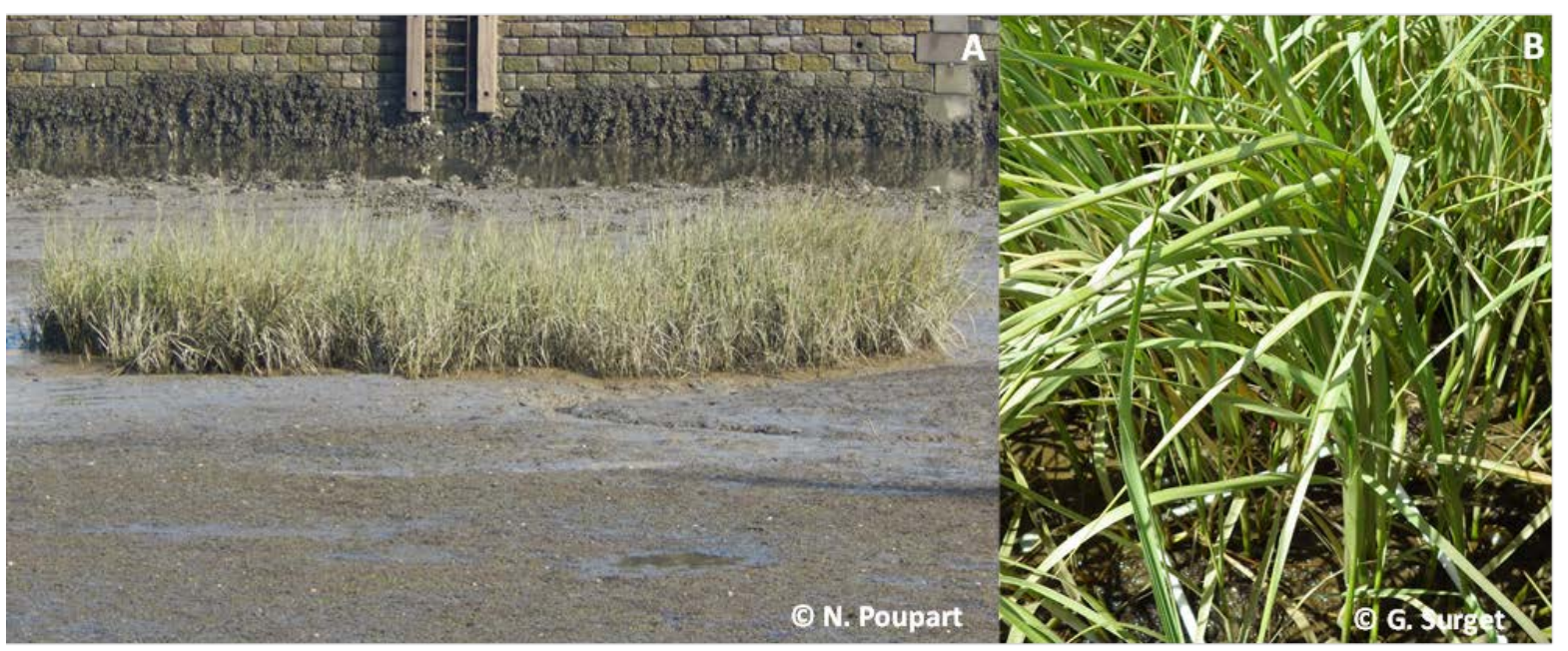

Figure 8. (A) Spartina alterniflora colonizing the upper zone of an intertidal mudflat. (B) Close-up view of the 2-D leaf blades.

a perennial sterile hybrid. After 1890, S. × townsendii fertile plants were recorded in England; they resulted from chromosome doubling in $S . \times$ townsendii, thus leading to the creation of S. anglica [35].

\subsection{Mollusks}

The main invasive species of benthic invertebrates in Brittany encompass Mollusk Bivalves (Crassostrea gigas, Venerupis philippinarum known before as Ruditapes philippinarum) and Gastropods (Crepidula fornicata, Gibbula albida), one Polychete species (Ficopomatus enigmaticus), 2 barnacle species (Cirriped Crustaceans: Elminius modestus and Balanus improvisus), one crab (Decapod Crustacean: Hemigrapsus takanoi, which competes with the native green crab), and one Tunicate (Styela clava). Only the case of the Mollusks is detailed below. 
The American slipper limpet, Crepidula fornicata L., is native of the East coast of North America (from Canada to the Gulf of Mexico); its introduction in Europe is ancient since it was first observed in the Bay of Liverpool in 1872. Introduction would be accidental, via repeated transfers of American oysters, Crassostrea virginica. The first observations on the European continent were made in 1911 in Belgium (Ostende). Along the French coasts, it was first observed in Calvados (Hermanville) and in the Bay of Brest in 1949, with a secondary dispersal in the English Channel and the Bay of Biscay. Nowadays, this species is found all along the Channel-Atlantic coasts (Figure 9); C. fornicata proliferates in bays and estuaries, reaching several thousands of individuals per $\mathrm{m}^{2}[36]-[40]$.

The mechanisms of its introduction in France (Figure 10) include: 1) introductions starting in the 30s due to seashell imports from England and the Netherlands; 2) a main introduction event in 1944 (during the second World War) on the Calvados beaches and in the ports of Cherbourg and Brest (the slipper limpets were attached to the hull of the landing ships), with a secondary dispersal along the Atlantic coast due to oyster transfers between culture areas; and 3) new introductions from British Columbia and Japan in the 70s. At that time, the Pacific oyster started to stand for the Portuguese oyster in European oyster farming, the latter being wiped out by diseases. Following the colonization of Atlantic oyster farms, all the French oyster farming areas, from Normandy to the Mediterranean Sea, have been progressively colonized by direct introductions. This third colonization phase corresponds to the proliferation phase along the French coasts.

Recent studies in population genetics have focused on $C$. fornicata colonization patterns. In particular, the study of genetic polymorphism of native populations (East-Atlantic coast) and alien European populations looked for potential successive colonization steps. Colonization history turned out to be difficult to track however, since the various populations are genetically much diversified [41]. Thus, genetic diversity within the Bay of Brest population is as high as diversity observed between several European populations [41].

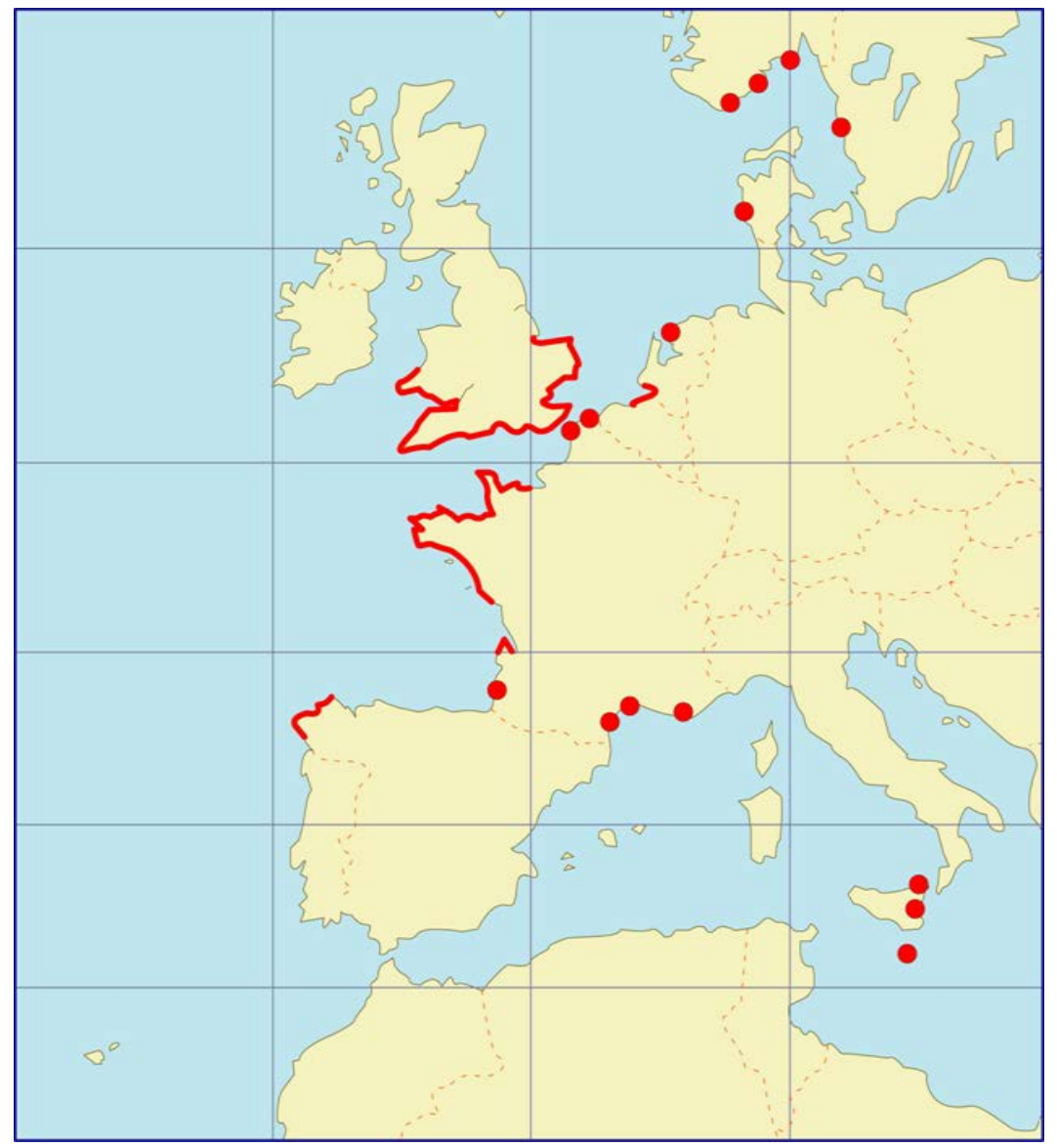

Figure 9. Distribution of the slipper limpet, Crepidula fornicata, in Europe in the 1990s (from Blanchard, 1997; [36]). 


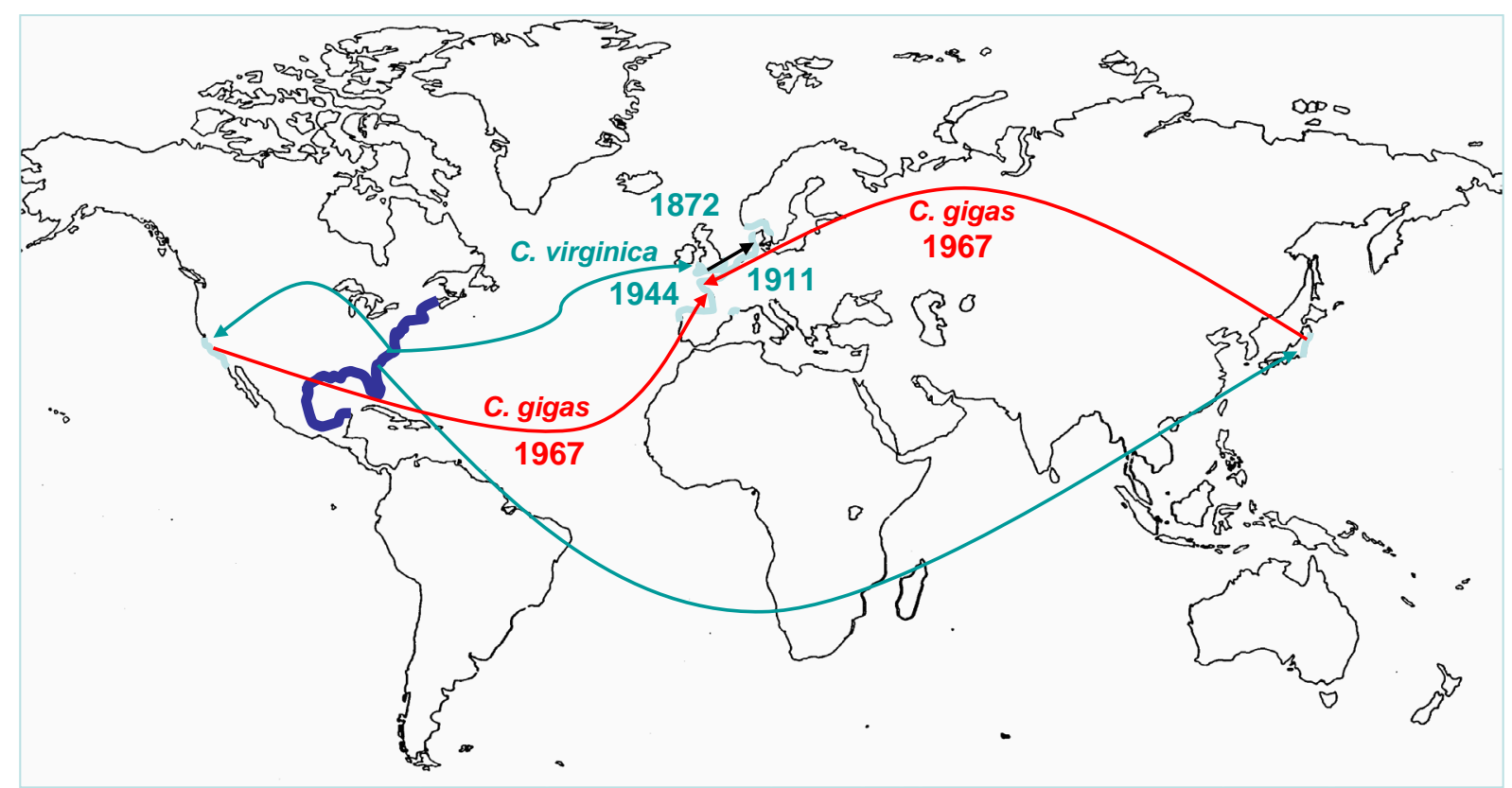

Figure 10. Main phases of introduction of the slipper limpet, Crepidula fornicata, in Europe (modified from [16]).

In the Bay of Brest, the slipper limpet proliferation was progressive, likely due to long-time changes in physico-chemical characteristics and trophic webs within the ecosystem. The first census in 1979 showed that the species was mainly located in the southern basin of the Bay and the oyster farms of the northern basin. A fast increase of the colonization process was recorded between 1995 and 2000 [39]: the slipper limpet biomass increased from less than 20,000 tons dry weight in 1995 to ca. 85,000 tons DW in 2000 (Figure 11). The Center of the Bay of Brest and the northern Basin were colonized at that time. However, carrying capacity of the Bay (i.e. the maximum biomass per surface unit that a given site can support) was reached locally in the southern Basin in 2000. Recent study by Ifremer in 2013 and 2014 showed strong decreases in total abundance and biomass of $C$. fornicata in the Center and southern Basin of the Bay of Brest (A. Carlier, Ifremer, pers. comm.). The reasons of this decline remain to be determined. Elsewhere in northern Brittany, the dynamics of Crepidula proliferation would have been faster, possibly due to earlier colonization. Total slipper limpet biomass in the Normand-Breton Gulf was estimated at 250,000 tons as early as 1974 [42], but speeding up of the colonization was also observed between 1996 and 2004 in the Bay of Mont Saint-Michel. Repeated slipper limpet stock assessments by Ifremer in this Bay showed that total biomass increased from 100,000 tons wet weight to 150,000 tons WW in the 8-yr period [40].

Crepidula fornicata, which is a protandrous hermaphroditic species [43], is ideal for investigating reproductive patterns in relation to sequential hermaphroditism. The patterns of gender allocation of this gastropod have been investigated for almost an entire century [see [41]], an interest largely due to its grouping behavior. This long-lived species (lifetime of ca. 10 years; [42] [43]) is typically found in stacks (i.e. groups of individuals attached to each other), with larger (older) individuals, usually females, at the base and smaller (younger) individuals, usually males, at the top. Because fertilization is internal and these groups are perennial, they generally constitute independent mating groups in which sex change occurs according to various factors including sex ratio, number and size of individuals within the stack [41]. The location of the individuals within a stack remains unchanged over time except for small individuals (male or immature), potentially imparting an advantage to males directly attached above a female. The female at the base of a stack is usually fixed on a dead shell of slipper limpet, valves of the King scallop, Pecten maximus (Figure 12), or any other hard substrate. The invasive potential of $C$. fornicata partly lies in the main features of its reproductive cycle: long reproductive period, annual reproduction with "multi-trials", high female fecundity, internal fertilization between the males on top of the stack and the females at the base, survival of brooded embryos and young larvae close to 100\% with embryos packed in thin-walled capsules attached to the substratum by a peduncle. The females incubate the capsules between the propodium and neck [44]. Larvae are spawned after a three-week larval stage in the capsules 

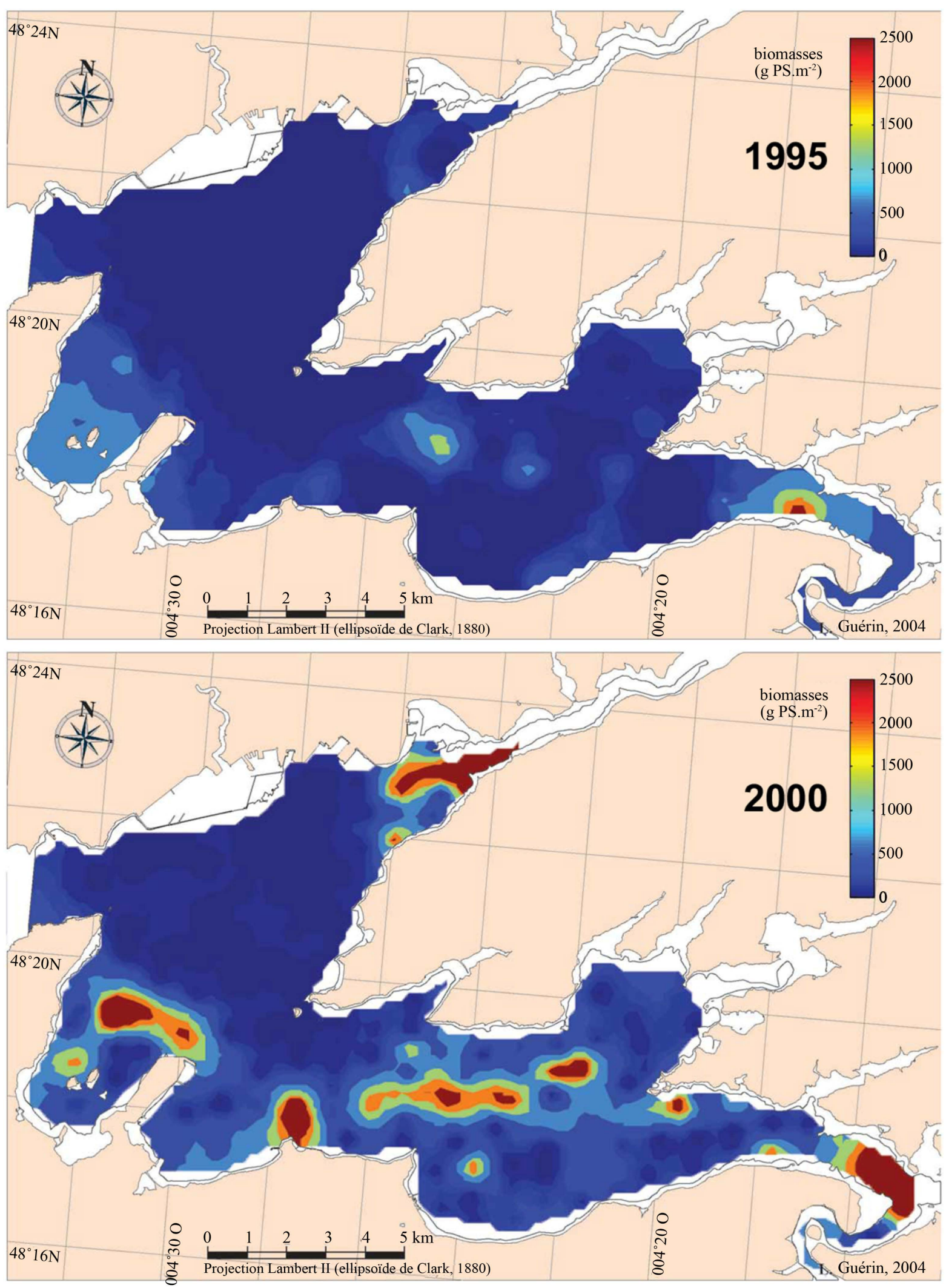

Figure 11. Dry biomass (g dry weight $\mathrm{m}^{-2}$ ) of Crepidula fornicata in 1995 and 2000 in the Bay of Brest (modified from [39]). Total biomass in the Bay increased from less than 20,000 tons dry weight in 1995 to ca. 85,000 tons DW in 2000. 


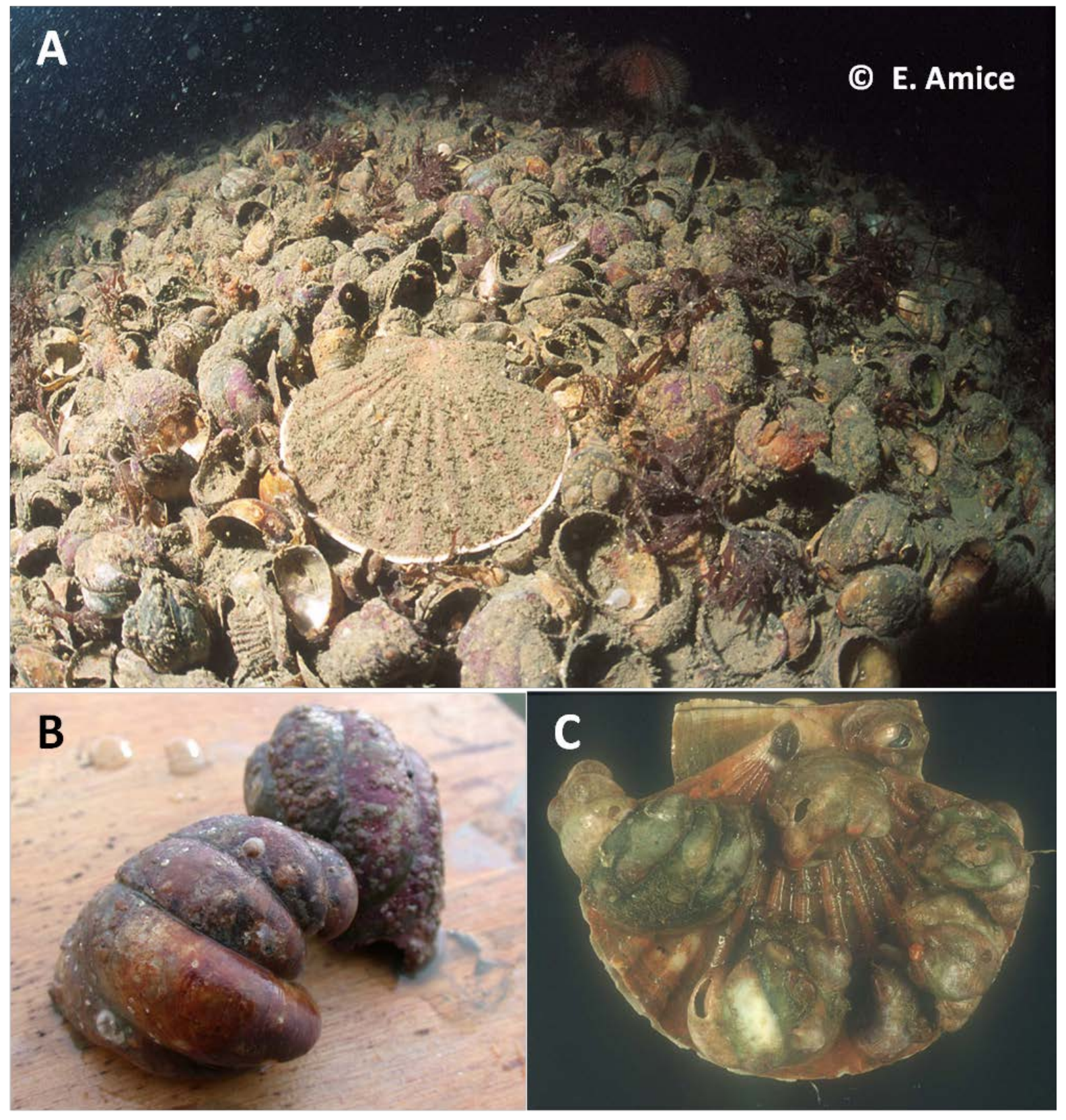

Figure 12. (A) View typical of the Crepidula fornicata community in the southern basin of the Bay of Brest in the early 2000s. (B) Free stacks of slipper limpets. (C) Crepidula Stacks settled on Pecten maximus valves.

only if environmental conditions are good for survival (e.g. no harmful algae bloom at that time). In the Bay of Brest, paternity assignment of larvae, sampled from a set of brooding females and carried out using five microsatellite loci, revealed that $92 \%$ of the crosses occurred between individuals located in the same stack [41]. These stacks thus function as independent mating groups in which individuals may reproduce consecutively as male and female over a short time period, a pattern explained by sperm storage capacity. Gregariousness and sex reversal are promoting reproductive insurance in this species. In addition, females are usually fertilized by several males of the stack (78\% of the broods were multiply sired), highlighting sperm competition [41]. Mating behaviors and patterns of gender allocation vary in concert across sites suggesting that multiple paternities might enhance sex reversal depending on sperm competition intensity.

The Pacific oyster, Crassostrea gigas, is a second example of introduced Mollusk species, whose proliferation 
along the French coasts is particularly dramatic. This oyster, native of South-East Asia, has been progressively introduced on all the continents since the mid- $20^{\text {th }}$ century (1960-70) for aquaculture purpose. This species accounted for $97 \%$ of the world oyster production in 2010 (http://www.fao.org/fishery/culturedspecies/Crasso strea_gigas/fr; 4.6 million tons in 2006). The Pacific oyster is now introduced in at least 48 countries, with wild populations being established in 17 countries. Acclimatization is not fulfilled in 19 countries while the species status still remains unknown in the last 12 countries [45]. The failure of species establishment in new natural environments would result from introduction in environments too warm and oligotrophic for survival (e.g. Fiji, French Polynesia, New Caledonia) or too cold for reproduction (e.g. Alaska). C. gigas has been introduced in France in the Marennes-Oléron and Arcachon oyster farms from the late 60s on, to replace the Portuguese oyster, Crassostrea angulata, which had been wiped out by two viral diseases. From 1971 to 1977, more than 10,000 tons of Pacific oyster spat were imported from Japan and ca. 560 tons of adult oysters from British Colombia [45]. Nowadays, the French oyster production is ranked 4th in the world, with 116,000 tons produced in 2006, but only 95,000 tons in 2010 due to summer mortalities (herpes virus).

The first oyster recruitments in the wild were observed in 1975 at Marennes-Oléron and Arcachon. In the 80s, a few wild recruitments have been observed to the north of the Loire River, but the colonization remained sporadic at that time. From the mid-90s on, reproduction events increased further North, in Brittany: colonization now extends, on the Channel-Atlantic coasts, from the Normand-Breton Gulf to the Spanish frontier (Figure 13). The Bay of Brest and the Morbihan Gulf are heavily colonized, with oyster wild stocks reaching 10,000 and 6420 tons wet weight on ca. 3 and $5 \mathrm{~km}^{2}$, respectively [45]. The wild oysters colonize preferentially the intertidal sheltered rocky substrates (Figure 14), but also the discarded oyster farming devices, the slipways or the piers. Oyster biomass can exceed $50 \mathrm{~kg} \cdot \mathrm{m}^{-2}$. Wild populations are also observed on mud and mussel beds. In the latter case, oysters settle on mussel shells.

C. gigas is a particular protandrous hermaphroditic oviparous species: the individuals are usually male during

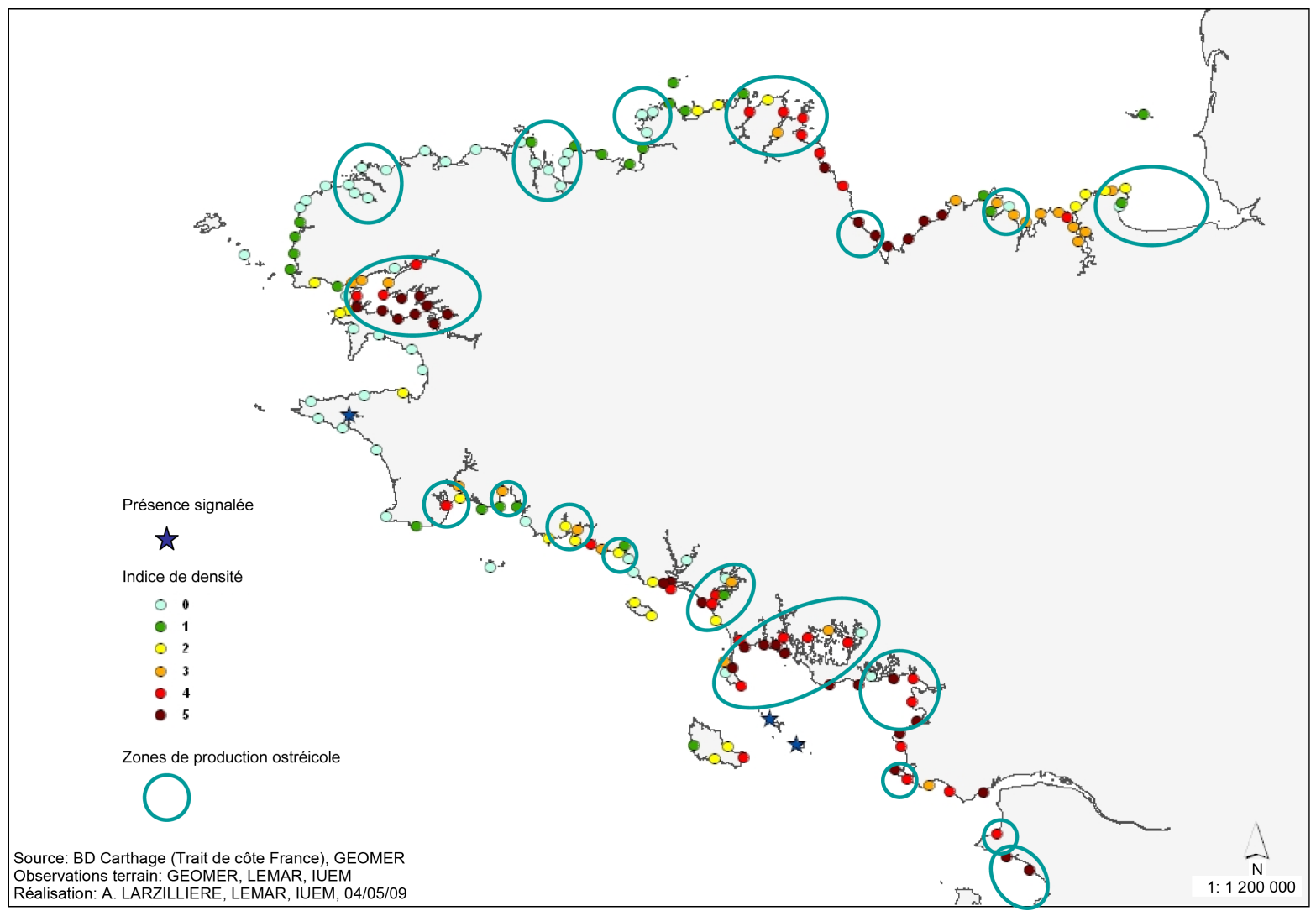

Figure 13. Colonization of the Brittany coasts by Crassostrea gigasin the late 2000s (from [45]). Signification of the density indices: 1: $<0.01$ ind. $\mathrm{m}^{-2}, 2: 0.01-1$ ind. $\mathrm{m}^{-2}, \mathbf{3 :} 1-10$ ind. $\mathrm{m}^{-2}, 4: 10-100$ ind. $\mathrm{m}^{-2}$, and 5: $100-1000$ ind. $\mathrm{m}^{-2}$. 


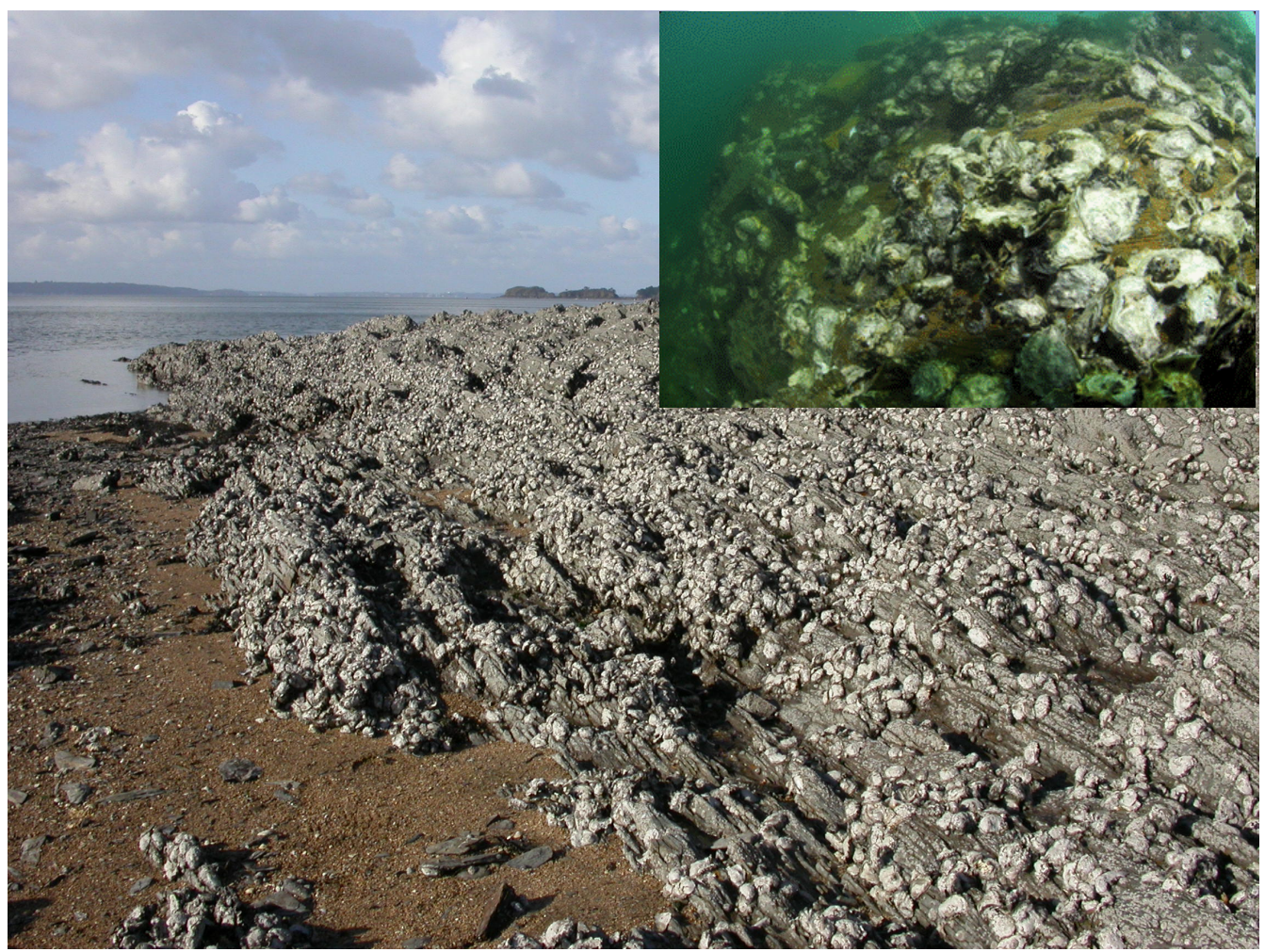

Figure 14. Proliferation of the Pacific oyster, Crassostrea gigas, on the intertidal rocky shore of the southern basin of the Bay of Brest (Moulin Mer) in January 2005. Close-up view at high tide (crédit: Erwan Amice).

the first year of reproduction and then they change sex from one reproductive season to the other (erratic changes). The oyster gonad is not a permanent organ. It develops around the digestive gland at each reproductive cycle during spring gametogenesis and declines after summer spawnings. C. gigas fecundity is very high: a single female can spawn up to 60 million oocytes in one spawning [45]. Spawning occurs in one or several trials in summer when water temperature is higher than $18^{\circ} \mathrm{C}-20^{\circ} \mathrm{C}$. Fertilization is external and the pelagic larval phase is going to last ca. 3 weeks before metamorphosis and post-larval settlement occurs. Coastal water warming since the early 90s would have increased $C$. gigas proliferation along the Breton coasts, except for the Abers region in the North Finistère where summer temperatures generally lower than $17.5^{\circ} \mathrm{C}$ preclude oyster reproduction. The Pacific oyster is also absent in the Bays of Douarnenez and Audierne because of no oyster farming in the area and tidal currents against larval drift for larvae originating from the Bay of Brest.

Third and last example of introduced Mollusk, the Manila clam, Venerupis philippinarum, is native of the North-West Pacific (from the Kuril Islands to Java) and the Indian Ocean (up to Pakistan at the West). The Manila clam was subsequently introduced to Hawaii in 1929 and to the North-West coast of the USA ten years later (accidental introduction). Naturally established populations are now present from Oregon to British Columbia. The species was introduced for aquaculture purpose on the French (Brittany, Marennes-Oléron and Arcachon; hatcheries and enclosure farming) and English Atlantic coasts between 1972 and 1980 [46]. Clam spat and mature individuals originated from the Seattle region and Puget Sound (USA). Manila clam farming quickly grew in the 80s, thanks to hatchery and growing techniques which were developed to fit the species requirements. However, Manila clam aquaculture is marginal in Brittany now, due to the brown ring disease (Vibrio pathogen) and above all competition with fisheries which developed on natural clam beds. Acclimation of the Manila clam to the wild has indeed generated large wild populations from 1987 on, from the northern part of Brittany to Arcachon, particularly in the Arcachon Bay and Morbihan Gulf. Whether the Manila clam competes for space and food with the native clam (Venerupis philippinarum) in these areas remains to be determined. At the European scale, natural populations are found on the South coast of Great Britain and all along the French and Spanish Atlantic and Mediterranean coasts (mainly in the Adriatic Sea). Venerupis philippinarum has also been reported 
from different other places in the world: Norway, California, Morocco, Tunisia, Israel and Tahiti (see [47]).

The Manila clam is an infaunal filter feeder that mainly lives in shallow embayments and estuaries. It is able to tolerate temporarily freshwater inputs at low tide and its bathymetric distribution ranges from high spring tide levels to a few meters deep into the subtidal zone. This species can be found in various soft sediments: coarse sand, sand, muddy gravel, mud and in Zostera noltii meadows. As attested by its wide geographic distribution, the thermal tolerance range of the Manila clam is wide; optimal growth temperature ranges from $20^{\circ} \mathrm{C}$ to $24^{\circ} \mathrm{C}$ [47].

Venerupis philippinarum is a gonochoric species. As in most venerids, its gonad is a diffuse organ within the visceral mass. Although exceptions can be found in cold waters, gametogenesis is initiated when water temperature rises over $12^{\circ} \mathrm{C}$ and lasts for 2 to 5 months before the first spawning events occur (see [47]). Spawning periods vary geographically. Along the French Atlantic coast, a major spawning event occurs in late August-beginning of September (see [47]), with all the individuals of the population spawning synchronously. Depending on the environmental conditions, several asynchronous partial spawnings can occur between May and the end of August. If environmental conditions are favorable, a late spawning event can still occur at the end of fall. Planktonic life lasts for 10 to 15 days and post-larvae exhibit an active substrate selection process at settlement in which they prefer sandy over muddy substrates [47].

\section{Impacts on the Environment}

The multiple ecological effects of invaders and their impacts on native species populations and related ecosystems have been widely documented [48] [49]. At the ecosystem level, invasive species influence the processes determining the carbon and nutrient cycling [50]-[55]. In aquatic environment, mollusks such as Dreissena polymorpha, Venerupis philippinarum, Potamocorbula amurensis, and Crepidula fornicata are among the most common invaders [36] [56]-[58]. These species are very active suspension feeders and their dense assemblages may exert strong influence on suspended particulate matter [59]. The feeding activity of filter feeders results in the packaging of suspended material into faeces and pseudofeces that settle to the bottom, diverting primary production and energy flow from planktonic to benthic food webs and increasing the release of dissolved end products of organic matter mineralization from the bottom [50]. In addition to stimulate benthic bacterial respiration through biodeposition, suspension feeders also release carbon through their own metabolism [53] [54] [56]. In shallow coastal waters, benthic communities dominated by dense populations of suspension feeders are important zones for carbon cycling and may dominate ecosystem processes and metabolism [60].

More generally, the consequences of biological invasions include at the same time impacts on the environment, the various compartments of the food webs (biotic interactions: competition, predation, parasitism, diseases, etc.), ecosystem functioning overall, and socio-economy (e.g. interactions with the biological cycles of exploited species like the King and Queen scallops). Whatever their origin, invasive species can lead to major changes in the structure, functioning and dynamics of coastal ecosystems. The main impacts of biological invasions relate to: 1) the marine habitats: substrate type, near-bottom hydrodynamics and shear stress, increased light penetration due to filter feeding, number of microhabitats (spatial and/or trophic niches); 2) the native biodiversity (strong decrease in general); 3) the ecosystem structure and functioning (sediment chemistry, biogeochemical fluxes, food web complexity, biotic interactions within the same trophic niche, etc.); and 4) the human uses of marine resources: yachting, fishing, aquaculture, tourism, etc. A review of the ecosystem engineering attributes of non-indigenous invasive bivalves can be found in [61]. Sargassum muticum, Crepidula fornicata and Crassostrea gigas are the three main biological models used in this section to illustrate the effects of the proliferation of alien marine benthic species on coastal ecosystems. Indeed, the former are among the species having the most detrimental impacts on French Channel-Atlantic coasts.

\subsection{Impacts of Sargassum muticum Proliferation}

S. muticum seems to be in regression now, while many ecological and economic impacts were noticed in the past. Nevertheless, this introduced species can still cause momentary awkwardness in summertime, but without comparison with the environmental disturbances of the 1980s.

Ecological impacts. When the populations become dense, Sargassum muticum competes for space, light and nutrients with the other benthic macroalgae. The important canopy formed by $S$. muticum during summertime creates a genuine screen, which prevents light diffusion (Figure 3(B)). It can thus reduce and even prevent the 
development of the other macroalgae. Part of the native Laminaria digitata forest was decimated by the arrival and proliferation of Sargassum muticum in the Channel in the 90s [13]. In fall, this phenomenon fades since the algae laterals often separate from the main axis and float or sink, which reduce the screen effect. The competition for space between S. muticum and the other macroalgae is stabilized today, in particular because of the adaptation of native species, like other macroalgae, epiphytes, or grazers like the sea urchin. As an example, S. muticum is now sharing space with the native Sargassaceae, i.e. Cystoseira baccata. or Bifurcaria bifurcata, in rock pools from Brittany [22] [62]. In some sites, the Laminariales species are rare or even totally absent because strong water turbidity precludes photosynthetic activity. In such habitat, S. muticum, which is much more tolerant, becomes a structuring species by providing shelter and protection to many associated fauna and flora (Figure $3(C)$ ). Fish larvae, adult fishes and crustaceans take refuge under the canopy while the cuttlefish drops off its eggs on the algae axis, etc. Once grounded as foreshore, S. muticum becomes a food source for amphipods.

Economic impacts. Several human activities are constrained in sites exhibiting strong density of S. muticum. Shellfish farming is the most impacted: 1) S. muticum settle on oyster shells in culture creating extra work at harvest; 2) The algae make harder the access to the oyster farms and maintenance of the culture devices: laterals of $S$. muticum roll up around the feet of mussel beds and oyster tables or settle on longlines and weigh down them; 3) The fishing activities are also impacted with navigation problems (propellers or turbines clogged by the algae) and fishing gears becoming inefficient (pots and nets overloading, hanging and loss of the hooks in the algal canopy, etc.). The floating vesicles of the macroalgae can also clog the engine cooling system.

\subsection{Impacts of Spartina alterniflora Proliferation}

Only ecological impacts are mentioned. Spartina alterniflora produces viable seeds and multiplies vegetatively by propagated rhizomes at the same time [34]. Generally, colonization starts from individualized circular spots which, by coalescence, end up constituting monospecific meadows with rounded contours. This pattern, which characterizes a clonal organization, clearly differentiates this species from the other vegetable formations of the intertidal zone. Few saltmarshes in Europe are colonized by S. alterniflora. In the Bay of Brest, a long-time study allowed understanding its expansion and characterizing its ecological consequences on the intertidal ecosystem. Observations carried out from 1952 to 2004 in three sites of the Bay [63] showed that S. alterniflora first settled on upstream sites, on mud de-salted by freshwater, and also on the upper parts of the bare slikke. Then, it gradually progressed towards the main channels together with the substrate raise. In the same time, new spots of colonization appeared downstream in the middle of the mud flats on both sides. Expansion continued in all the directions including within the schorres already present; the latter were progressively colonized starting from the upper slikke and the secondary channels. Today, many areas of the Bay are largely covered by S. alterniflora, with considerable impacts on the environment as shown by the conceptual model of changes that Spartina can generate on physical, chemical, and biological processes (Figure 15). Spartina reduces light and tidal water flow and increases deposition of fine sediments and sediment organic matter. The increased belowground biomass together with changes in the sediments results in increased levels of sulfide and decreased ammonium levels, which can negatively affect other plants and animals [64]. These changes result in increasing detrital loads and decreasing productivity of benthic microalgae, which favor subsurface deposit feeders and detritivores at the expense of grazers, suspension feeders, and surface deposit feeders. The shift toward smaller, subsurface species may reduce invertebrate food resources for larger consumers such as crabs, birds, and fishes [64].

S. alterniflora first impacts the sedimentology of the colonized areas, because the species is an ecosystem engineer, i.e. a species able to create, maintain, modify, or destroy their habitat, and is capable to collect the sediments [65]. Indeed, its rigid stems decrease tidal flow rate, causing suspended sediment to precipitate, while the dense rhizomes system traps the sediment [65]. In New Zealand, sediment accumulation rates of $4 \mathrm{~cm} \cdot \mathrm{yr}^{-1}$ have been reported in S. alterniflora meadows, while adjacent bare mud showed no change. Still in New Zealand, the introduction and the expansion of S. alterniflora and S. anglica are responsible of an accumulation of sediment likely draining the marshes and the mangrove swamps [66]. Another interesting aspect is the capacity of $S$. alterniflora to provide a substratum for a diverse assemblage of epiphytic microalgae that contribute significantly to saltmarsh primary production and estuarine nitrogen fixation [64]. Moreover, S. alterniflora is a siliceous plant which can potentially act like a silicon pump and modify biogenic silica recycling and silicate inputs to the coastal environment. By comparing invaded and not invaded salt marshes, Querné et al. [67] estimated that Si retention is 2 -fold higher in the invaded marsh (8\%) than in the free marsh (4\%). Moreover, biogenic silica bu- 


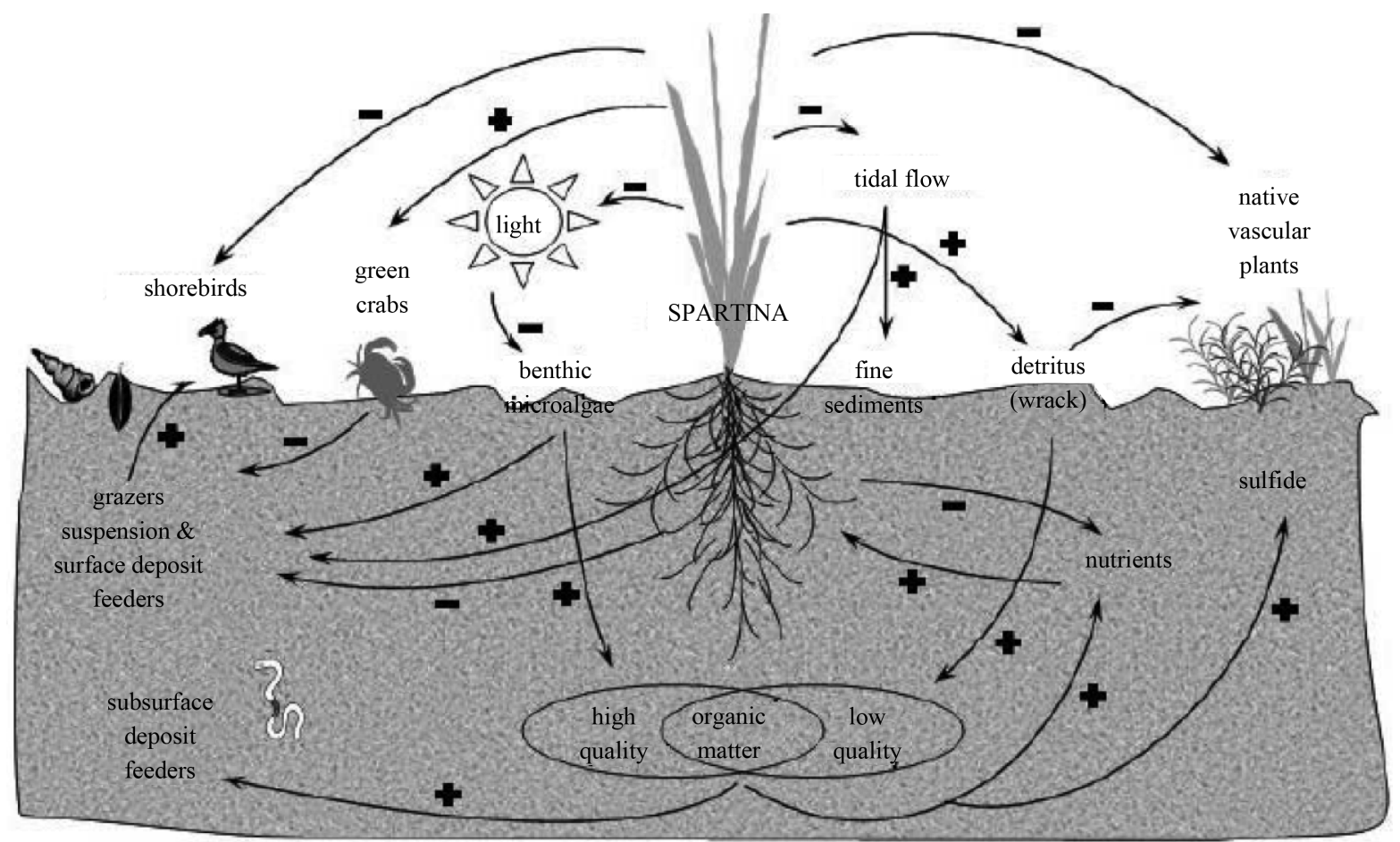

Figure 15. Modifications in ecosystem structure and functioning due to the invasion of Spartina alterniflora on salt marshes, showing positive $(+)$ and negative (-) effects on a range of physical, chemical and biological processes (from [64]).

rying increases by $50 \%$ in the colonized salt marshes.

As to native communities, introduced Spartina species are often inferred to outcompete native saltmarsh plants in the intertidal zone. The ecological impacts of Spartina invasions have been documented primarily through observational studies. The invader develops in spots which progressively join and constitute monospecific meadows being responsible for native species extinctions in some cases. Moreover, S. alterniflora often has a canopy higher than that of the native species, which reduces significantly light penetration to the sediment interface [68]. Consequently, the production of benthic microalgae is much weaker in salt marshes invaded by Spartina and dominant primary producers switch from benthic microalgae to Spartina [68]. The expansion of S. alterniflora in the Bay of Brest resulted in the replacement of annual halophyte communities such as glassworts Salicornia procumbens, Suaeda maritima, and Halimoine portulacoides, but also Limonium humile, a protected perennial species whose only populations in France occur in the Bay of Brest (UICN red list since 1995) [69]. Post-invasion changes in the physical and chemical characteristics of the environment have also major impacts on the benthic macrofauna. The development of the canopy allows an increase of the epifauna [68], while the important biomass of Spartina rhizomes and changes of organic matter quality resulting from the dead biomass lead to a significant reduction of the infauna diversity [70]. The benthic macrofauna switches from a community dominated by filter feeders to a detritivore-dominated assemblage [64] [71]. Finally, shore birds face habitat loss for food due to the reduction of the bare mud zones in the colonized areas [64] [72] [73].

\subsection{Impacts of Slipper Limpet Proliferation}

Ecological impacts. Many experimental and in situ studies performed in the Bay of Brest showed that $C$. fornicata would play a key role in ecosystem functioning as an ecosystem engineer [74] and biological filter [37] [38] [51]-[55] [75]. The latter does not help sustainable management actions such as dredging-regulated biomass decreases for environmental restoration in the Bay. C. fornicata colonized more than half of the benthic surface area in the early 2000s [39] and induced both economic and ecological consequences through disturbance of mollusk cultures and fisheries, and shifts in benthic community species composition and trophic structure [37] [38]. The ecological risk associated with the proliferation of the slipper limpet was due to increased competition for space and food between benthic species (the colonized surface area increased from $45 \mathrm{~km}^{2}$ in 1978 to $90 \mathrm{~km}^{2}$ 
in 1995) and biodeposition rates extremely high. If the reasons of increased colonization rate in the late 1990searly 2000s remain unknown, the ecological impacts of Crepidula proliferation on the sediments, other benthic species and ecosystem functioning have been well established:

- Sediment silting due to biodeposit production (faeces and pseudofaeces) by the slipper limpet [37] [76];

- Decrease of macrofauna species richness at Bay scale (70 species were considered endangered in 1998; [76]) due to bottom homogenization and constitution of a faunal assemblage typical of the Crepidula community (whatever the original assemblage before colonization);

- Decreases of the King scallop (Pecten maximus) and Queen Scallop (Aequipecten opercularis) stocks and distribution areas in the Bay, the latter presenting an exclusion relationship with $C$. fornicata [37] [76]. This negative interaction between scallop species and the slipper limpet is due to the fact that scallop post-larvae cannot settle and survive on muddy Crepidula bottoms. Stock decrease, increased production costs (more time required to sort the dredge contents and clean the scallop shells) and recurrent toxic events due to harmful Pseudo-nitzschia blooms and domoic acid bioaccumulation in the King scallop digestive gland have led to the fishery closure in recent years;

- Control of the phytoplankton primary production (annual microalgal total biomass and species succession). Several studies [38] [51]-[55] [75] showed that 1) the decrease of chlorophyll biomass during the first spring bloom would result from silicic acid limitation and increased suspension feeder activity; 2) benthic filtration and biodeposition activities would enhance biogenic silica retention at the sediment-water interface; and 3) recycling of trapped biogenic silica would maintain diatom populations by providing silicic acid in summer and would reduce primary production seasonality. These results suggest that benthic organisms control the export rate of biogenic silica towards the open-water ocean and thus the specific composition of secondary phytoplankton blooms in the Bay;

- Impact on the hydrodynamics and transport properties of the benthic boundary layer. These results were obtained combining three different approaches: 1) in-situ measurements of near-bottom current and suspended sediment concentration on two sites in the Bay of Brest (high vs. low Crepidula density); 2) velocity measurements in controlled laboratory experiments of flows over a bed of artificial Crepidula shells and 3) numerical simulations of the flow over two-dimensional shell-like bed forms [74]. Numerical and laboratory experiments showed that both the bed erosion and the exchange velocity between the canopy and the outer flow decrease as the roughness density increases. These results suggest a sheltering effect by the Crepidula shells increasing with the surface density of shells. This trend was also found in field measurements: during spring tides, higher particle resuspension was observed on the muddy sand bottom with few chains of slipper limpets compared with the high-density area. $C$. fornicata is a main ecosystem engineer whose shell stacks would modify food availability for suspension feeders and surface deposit feeders;

- Changes in biogeochemical fluxes at the water-sediment interface $\left(\mathrm{O}_{2}, \mathrm{CO}_{2}\right.$, nutrients). In the early 2000s, the estimated annual Crepidula community respiration in the whole Bay of Brest was found higher than the overlying phytoplankton and microphytobenthos carbon production in the bay [54]. C. fornicata is thus considered as a source of carbon influencing $p \mathrm{CO}_{2}$ in seawater and favoring $\mathrm{CO}_{2}$ effluxes to the atmosphere. The proliferation of $C$. fornicata since the pre-invasion, 50 years before, to the 2001 situation would have

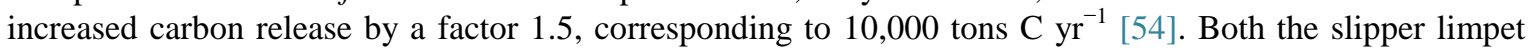
respiration and shell calcification contribute to carbon release, since carbon release by $C$. fornicata shell calcification represents $20 \%$ of carbon release by $C$. fornicata respiration [53]. The respiration of the other components of the community, micro-, meio- and macro-organisms, also contributes to the increase of $p \mathrm{CO}_{2}$ in seawater. Community respiration in sites with high $C$. fornicata densities in 2000-2001 (530 $\left.\mathrm{g} \mathrm{C} \mathrm{m}^{-2} \cdot \mathrm{yr}^{-1}\right)$ falls within the highest range of values reported for communities displaying high mollusk densities (230 $600 \mathrm{~g} \mathrm{C} \mathrm{m}^{-2} \cdot \mathrm{yr}^{-1}$; see review in [56]). At global scale, calcified benthic organisms living in estuaries would produce as much $\mathrm{CO}_{2}$ as the Great lakes or the whole Earth volcanoes [56]. This biogenic source of $\mathrm{CO}_{2}$ is increasing constantly due to continuous mollusk introductions and high capabilities of the latter to colonize new habitats.

The researches performed in the Bays of Saint-Brieuc and Bourgneuf, and in the Marennes-Oléron and Arcachon basins led to results partly similar on the impacts of $C$. fornicata proliferation in these ecosystems, though colonization dynamics exhibited local characteristics [77]-[80].

Economic impacts. In the Bays of Brest and Saint-Brieuc, the slipper limpet proliferation threatens the sustainability of scallop (Pecten maximus) fisheries. In the Bay of Brest, the local fisheries committee has initiated 
in the mid-2000s a containment project intending to make the scallop restocking program consistent with the alien species presence in the fishery. The issue is complicated by the occurrence of harmful microalgae blooms affecting the scallop fishery. A model dealing with the economic impact of the invasive process and a methodology for cost-benefit analysis of invasion management have been realized [81]. The invasion has a marginal direct cost, because fishermen have to scrape $C$. fornicata fixed on scallop shells on board, and a major indirect cost due to the reduction of habitat suitable for scallops. According to numerical simulation, the invasion is a serious threat to the economic viability of the restocking program and invasion management would help maintaining the long term sustainability of the fishery. Recurrent algal blooms cut the initial net present value of the traditional scallop restocking program by approximately $25 \%$, and the invasive process reduces it by approximately two thirds. Combining restocking and local control of the invasive process could reduce the cost of invasion by $55 \%$ in present value terms. Sensitivity tests highlighted the importance of long term equilibrium scallop catches on the program results, depending on scallop farming technical performance and ecosystem disturbance. In particular, sensitivity tests suggested that uncontrolled consequences of harmful microalgae blooms occurring more than every two years would definitely ruin the economic sustainability of the restocking program, whether or not associated to local invasion control.

In the Bay of Saint-Brieuc, where the biological invasion by $C$. fornicata is addressed by a control program, a bioeconomic model of the commercial scallop fishery has also been established [82]. The model combines the dynamics of the two competing stocks and analyzes the equilibrium of the fishery under various assumptions concerning invasive species control. According to the simulations, the control program generates a cumulated global present value which is greater by approximately 25 percent than the laissez-faire scenario, whatever the variant considered for the invasive species harvest function. Moreover, invasive species control allows sustainable fishing, while the laissez-faire scenario implies long term non-sustainability. The results emphasize also the importance of the starting date of the control program. Postponing this date is not neutral, because the level of invasion which is to be addressed by the program is time-dependent, and the discounted present value of a set of cash flows depends on their time-pattern.

\subsection{Impacts of Crassostrea gigas Proliferation}

Ecological impacts. The impact of Crassostrea gigas proliferation on native intertidal communities is variable. The Pacific oyster's large filtration capacity and eco-engineering characteristics induced many changes in receiving ecosystems. All estuaries are not affected in the same way; in the Dutch Oosterschelde estuary, expanding stocks saturate the carrying capacity whereas in the Wadden Sea no such problems exist [83]. According to the latter, the Pacific oyster seems to fit well within continental NW European estuarine ecosystems and there is no evidence that the invader outcompetes native bivalves. In the Netherlands and neighboring countries, C. gigas induces major changes in plankton composition, habitat heterogeneity and biodiversity, carrying capacity, food webs and parasite life cycles [84]. In particular, C. gigas may change entire ecosystems through cascading effects on other trophic levels. Thus, the increased filtration pressure in the Oosterschelde estuary due to an increased oyster stock already appears to have affected the phytoplankton community [83]. The oysters exert a top-down control on phytoplankton abundance and composition that may in turn affect higher trophic levels in the food web (e.g. zooplankton $\rightarrow$ fish $\rightarrow$ fish-eating birds and seals). Similarly, the oysters might induce cascading effects by exerting a top-down control on zooplankton abundance and composition.

In Brittany, the impact of the Pacific oyster on native communities is low as long as the oyster distribution stays 2-dimensional (low to moderate oyster densities). By contrast, when colonization amplifies and 3-D oyster reefs start to develop on the rocky shore or the mudflat, the impacts on benthic communities become obvious [45] [84]. Total abundance and species richness of the macrofauna are higher on oyster reefs and the relative abundances of taxonomic and trophic groups are modified. By contrast, the analysis of sediment grain size, sediment organic matter content and ecological groupings did not reveal any perturbation of the infauna due to organic matter enrichment. Opposite trend was found on rocky substrates of Bahía Anegada (Argentina) where C. gigas reefs trap sediments at higher rates than bare rocky platforms, increasing the habitat available for infaunal polychaetes (see [61]). Last, the comparison of benthic species associated with oyster reefs on Breton rocky shore and soft bottom did not highlight homogenization of intertidal communities, contrary to what is observed for the slipper limpet community.

The studies undertaken in Brittany did not allow showing an impact of oyster reefs on mobile predator abun- 
dances (fishes, crustaceans and birds). These impacts have been demonstrated elsewhere (see [45] [83] for review). In the Wadden Sea for example, the proliferation of oyster reefs on the intertidal mudflats would be responsible for the disappearance of the oystercatchers (Haematopus ostralegus). In the Bay of Brest, changes in diet behavior have been observed for the herring gull (Larus argentatus): the birds have learnt to feed on adult oyster specimens who drop off the reef and stay lonely on the sediment. Thus, the herring gulls have developed complex behaviors, the oysters being dropped off from several meters high, even several times in a row, until the oyster shells smash [45].

Oyster proliferation does impact biogeochemical cycles at the water-sediment interface. The study of oyster reef respiration and calcification in the Bay of Brest [85] has shown that C. gigas does not breathe during the emersion time, contrary to other intertidal species [86]. Only the biofilm living on the oyster shells contributes (for 3.5\%) to the oyster $\mathrm{CO}_{2}$ total production during low tide. Oyster $\mathrm{CO}_{2}$ production (respiration) only occurs during the flood. Carbon annual production by oysters, $36 \mathrm{~g} \mathrm{C} \mathrm{m}^{-2} \cdot \mathrm{yr}^{-1}$ [45] [85], is similar to carbon production of another intertidal species, the barnacle Chthamalus montagui [86]. Carbon total annual production of the rocky shore intertidal community would be multiplied by 20 (762 $\mathrm{g} \mathrm{C} \mathrm{m}^{-2} \cdot \mathrm{yr}^{-1}$ ) when C. gigas occurs in high density (700 ind $\mathrm{m}^{-2}$ ), compared with a substrate without oyster [86]. If the $3 \mathrm{~km}^{2}$ colonized by C. gigas in the Bay of Brest were covered by this oyster high density, the annual carbon production of oysters would correspond to the mean annual production of more than 1100 cars of medium engine size (mean production of $175 \mathrm{~g} \mathrm{C}$ $\mathrm{Km}^{-1}$ and mean distance travelled per year of 12,230 Km; SOFRES 2005 data). C. gigas does not impact the intertidal community respiration at low tide, but oyster reefs would favor benthic primary production: the reefs would protect the microalgae from desiccation and high lighting, thus limiting photoinhibition in summer.

Socio-economic impacts. The Pacific oyster proliferation along the NW European coasts generates also various nuisances for the users of the maritime domain. The colonization of harbor facilities (piers, wharfs, etc.) and aquaculture devices increases maintenance activities (the damages of nautical equipment can be important). The multiplication of sharp-edged oyster reefs in the intertidal zone disturbs people moving and increases the risk of being cut for foot-walking fishermen and swimmers. Finally, and unlike subtidal invasive species, oyster proliferation leads to clearly visible landscape transformation not always well accepted by the users. For oyster farmers, the proliferation of wild oysters within the farms is two-edged: it allows collection of wild oyster spat which is resistant to Vibrio-regulated summer mortalities, but the extra costs due to the cleaning of aquaculture devices may be prohibitive. Some oyster farmers of the Bay of Brest are currently transferring their production in the Aber Benoît or in the Paimpol sector (Côtes d'Armor), i.e. sites where wild recruitment does not occur. Cleaning the seabed from dead oyster shells is also a main concern in the Arcachon basin where the biomass of dead shells has been estimated to 50,000 tons Wet Weight in 2011 [87]. By contrast, the development of oyster reefs may compensate for habitat loss and biodiversity loss in estuarine environments that were caused by human activities in the previous decades. In the Wadden Sea, oyster reefs may in the future play an important role in the capturing of sediment and the protection of tidal flats from erosion, thereby buffering the effects of sea level rise due to global warming [83]. In the Arcachon Basin, the biomass of wild oysters (65,000 tons vs. 16,600 tons WW in culture) could sustain oyster farming which is facing massive summer mortalities. Spat collection and harvest of wild oysters on the mudflat are two management options proposed by the French Marine Protected Areas Agency, together with the creation of protected zones to maintain spat production potential [87].

\section{European Regulations Existing to Limit Introduction of Alien Species}

The environmental awareness of the risks related to the biological invasions is relatively recent. Many international conventions emphasize the need for containing them; the 1982 Montego Bay Convention on the Law of the Sea (http://www.un.org/depts/los/convention_agreements/texts/unclos/unclos_e.pdf) stipulates in particular that "the States must take all the necessary measures to prevent, reduce, and control the intentional or accidental introduction in the marine environment of foreign or new species which can cause considerable or harmful changes”. The BWM (Ballast Water Management) Convention of the IMO (International Maritime Organization), adopted in February 2004, imposes the exchange from at least 95\% of the volume of ship ballast water at least at 200 nautical miles from a coast and in water depth higher than or equal to $200 \mathrm{~m}$. This convention includes also a standard (BWPS, for Ballast Water Performance Standard), which sets limits at the number of lived organisms released with ballast water. This standard will be applicable only when the new ships will be equipped with systems of water treatment (by 2016 normally). As for the BWM convention, it requires 30 sig- 
natory countries to come into effect, which is not yet the case: at the end of 2009, only 18 countries had signed this convention including four European countries (Spain, France, Albania and Norway). Yet, there is no international legislation enforced with regard to ballast water exchange in the open sea [3]. In France, the Strategic Action Plan for marine environments set by the Ministry for Ecology and Sustainable development (MEDD) recommended in 2005 to support a well-argued management of marine areas and to preserve the marine natural heritage and biodiversity (short note No. 3). The setting of a "plan of intervention against the invading exotic species" was one of the identified actions, without knowing how, nor with which means, this plan could be implemented.

\section{Struggle against the Invaders: Eradication or Sustainable Management?}

Invasive alien species represent the second most significant cause of species extinction worldwide after habitat destruction (https://www.iucn.org). They are often accompanied by serious healthcare consequences and can be a threat for animal and human health, or result in considerable economic and financial damages. They can compete with native species, act as pests or pathogens for cultivated or domesticated species, or even disseminate allergic or infectious agents. Three strategies are possible to struggle against the invaders: 1) eradication, always difficult, even impossible; 2) control, i.e. maintaining the abundance of the introduced species at a level such as its ecological or economic consequences become bearable: this control must be repeated regularly and is an expensive process; and 3) prevention: the most effective and least expensive strategy, it requires nevertheless the setting up of an effective legislation on a worldwide scale.

\subsection{Eradication Trials and Biomass Control}

To date, there are few examples of successful eradication or effective struggle against marine invasive species [88]. The reasons may vary, but it is clear that the multiplication of the vectors of introduction makes the introductions of species difficult to control. Eradication is not, a fortiori, possible when it relates to an edible species like Crassostrea gigas, whose exploitation generates important incomes.

There is a well-accepted set of conditions which must be met for the eradication of any population. These standard conditions for success include proper planning, putting the entire population of the invader in jeopardy, removing the individuals faster than they reproduce, and preventing re-invasion. Additional conditions are support from local people and the ability to demonstrate the benefits of the eradication project. The case of Caulerpa taxifolia in California is meaningful: field containment and treatments began 17 days after the notification of infestation in Agua Hedionda lagoon on June 12, 2000. Three well-integrated components of this rapid response would have resulted in an effective eradication program: 1) expertise and knowledge on the biology of C. taxifolia; 2) knowledge on the uses, "ownership" and characteristics of the infested site; and 3) knowledge and experience in the implementation of aquatic plant eradication [88]. Together, with the requisite resources (approximately \$US1.2 million per year), this approach has resulted in containment, treatment and excellent progress toward eradication of $C$. taxifolia. Elsewhere, few marine invasions have resulted in response actions and, among them, a limited number have succeeded. Two examples of eradication trials on the French Channel-Atlantic coasts, which gave opposite results, are given below.

The brown macroalga Macrocystis pyrifera, also called the giant kelp, represents one example of eradication success in Brittany. This species was introduced in Brittany in 1970s for aquaculture to develop the industry of alginates. M. pyrifera produces a high-quality alginate allowing good yields for harvesters [89] [90]. It was first recorded in 1972 in Roscoff [16]. Its cultivation in Brittany was permitted on the basis that low water temperatures would preclude reproduction by spores. Nevertheless, its cultivation was banned later on in Normandy when it was clear that the alga could complete its reproductive cycle with the temperatures occurring in the English Channel and the North Sea [91]. In Brittany, it was decided to eradicate M. pyrifera when considering its competition with native laminarian species on rocky shores. Eradication was successful because the giant kelp was found only in its introduction sites on rocky substrates, thus limiting the likelihood of dispersal, and because only small populations with low reproductive rates were introduced.

The winkle Japanese oyster drill Pteropurpura inornatus is a good illustration of the difficulty of fighting against the proliferation of an alien species. This exotic predator, a little bit larger than the indigenous winkle driller, Ocenebra erinacea, is native of the North-West Pacific. It initially invaded the East coast of the Pacific between 1920 and 1940 and was first observed in the Marenne-Oléron basin in 1995. P. inornatus would have 
been introduced with Pacific oyster imports. This winkle driller is a bivalve predator generating increased predation on cultivated oyster stocks. It is likely to compete with $O$. erinacea, the two species occupying the same ecological niche. The localized initial distribution (Marenne-Oléron) of $P$. inornatus - one did not find it in the Ré Island for example - aroused eradication tests as soon as its first records. Three types of actions were undertaken, primarily by the Regional Section of Conchyliculture: 1) destruction of the ovigerous capsules using propane burners; 2) incentive harvest operations in the intertidal zone; and 3) pot fishing using oyster meat like bait. Today, the species is present from Brittany, except perhaps for Finistère, to Arcachon Bay; it is considered invasive on the Breton coasts (http://www.bretagne-environnement.org/especes-invasives/).

The relevance of the measures of struggle against the invader, often wished by the various categories of users impacted by the biological invasion, is not always obvious; the case of Crepidula is a good illustration in two ways. 1) In the Bay of Brest, during the early 2000s, bottom cleaning (dredging of Crepidula) on a large scale was once planned in order to grow hatchery-produced scallop juveniles in areas which had become unfavourable for scallop survival and growth. However, several studies emphasized the potential role of biological filter played by C. fornicata in the Bay. In particular, filtration and biodeposition activities of Crepidula and benthic remineralisation were found to sustain summer diatom production whereas the dystrophic conditions in summer should lead to the recrudescence of non-siliceous microalgae species (of which the toxic dinoflagellates) [38]. Thus, large-scaled bottom cleaning at that time could have had disastrous consequences on ecosystem functioning and survival of commercially exploited species. In 1995, summer blooms of Gymnodinium cf nagasakiense led to mortality of all the scallop post-larvae produced at the Tinduff hatchery, no recruitment of scallop juveniles in the wild and strong decreases in daily shell growth of 1-year-old and older individuals (juveniles and adults). The risk to see increasing summer blooms of toxic phytoplankton species could not be neglected, because of the excess of nitrate and the associated silicate shortage in river inputs. 2) In the Bays of Saint-Brieuc and Cancale, massive extractions of Crepidula were carried out between 2002 and 2007. Two ships extracted 110,000 tons WW (instead of the 175,000 tons initially scheduled) before the dredging was stopped. In addition to the lack of profitability of the project, one could note that the bottom-cleaned zones were recolonized very quickly. This pattern may be related with data from Arcachon Bay showing that the Crepidula P:B ratio was higher in sites where this species was facing anthropogenic perturbations [92]. On the whole, more than 1.5 million euros would have been spent to remove Crepidula from northern Brittany, without convincing result (Ouest-France, edition of June 15th, 2007).

Crassostrea gigas is an example for which both eradication trials and control of the wild biomass have been performed (see [93] for review). In Australia, C. gigas is considered a noxious species in areas where it can outcompete native oysters. A comprehensive methodological approach to best practices for the management of introduced marine species has been developed by the Australian Global Invasive Species Program. Notably, including lessons from terrestrial bioinvasions and clues to evaluate the side effects of eradication methods, this approach also stresses the importance of risk assessment, surveillance, and the development of adequate information, coordination, and legislative tools. Information tools have been developed by the National Introduced Marine Pest Information System (NIMPIS; http://www.marine.csiro.au/crimp/nimpis/; http://adl.brs.gov.au/ma rinepests/), which also aims to provide potential control options. However, none of the methods described have proven to be totally effective for the eradication of C. gigas [93]. A similar approach has been enforced by northern European countries, where the Nordic-Baltic Network on Invasive Species database (NOBANIS; http://www.nobanis.org), based on the Australian information system, was implemented. However, despite these efforts, the Netherlands is the only European country where significant mass reduction trials have been conducted. In France, several studies have been carried out in the Marennes-Oléron Basin, the Gulf of Morbihan, Bourgneuf Bay, and at a national level. The collection of such data is an essential preliminary step towards the determination of the most appropriate actions, taking into account the particular characteristics of individual sites [93]. The Marennes-Oléron Basin is an example of successful reduction measures. Indeed, the restructuring of leases in the Basin, enforced over the last 15 years, allowed a significant reduction of wild stocks in farmed areas. The thorough removal of wild C. gigas and, at the same time, its trophic competitor Crepidula fornicata and predator Ocinebrellus inornatus, involved the use of powerful caterpillar tractors and snow ploughs especially equipped for marine activities.

\subsection{Valorization of Invasive Species}

When eradication cannot be set up, a possible way of regulating the proliferation of invasive species is the ex- 
ploitation of their important biomasses. Thus, the invaders become potential marine resources for diverse industrial sectors. According to the species, various types of valorization are looked for. In Brittany, the marine macroalgae being exploited are Sargassum muticum, Grateloupia turuturu, Codium fragile and Undaria pinnatifida. S. muticum proves to be a species producing active biomolecules acting like anti-microfouling [21] [94]-[97] (interest for shipyards). Antioxidant molecules and anti-inflammatory drugs were also isolated from S. muticum [22] [23] [98]-[102], with potential outlets in the cosmetics and Para pharmacy sectors. G. turuturu also produces anti-microfouling molecules [95] [103] and molecules which act against the European abalone pathogen Vibrio harveyi [104], as well as great quantities of R-phycoerythrin red pigment interesting various industrial sectors [105] [106]. This species was also studied for its biochemical composition to be proposed as an edible species [107]. C. fragile is exploited for cosmetics in Brittany [30] and Undaria pinnatifida for agri-food (4 tons of algae collected from algoculture in Brittany in 2008). The natural populations of the latter are not exploited, due to biomasses being not sufficient.

With regard to Crepidula fornicata, several attempts have been made until now (fresh product or transformation into fertilizers, limestone soil enrichment product and feed meal) with poor success, due to low economic profitability. The current studies, in the field of human health, are directed towards the search for active molecules with high added value. Antimicrobial properties, the chelation of heavy metals or the trapping of phosphate are targeted. The food trail was also revived by 3 Breton SMBs, with the opening of a treatment plant of Crepidula in Cancale in January 2009. Three shipyards from Cancale supply the factory which is expected to treat 10 to 20 tons per day. The sector of exploitation is double: the meat is used to design new dishes in agribusiness industries, whereas the shell is exploited to replace the maërl as marine soil enrichment product or to produce pet food (calcium supply), once crushed. Today, a SMB (www.Britexa.com) also markets this shellfish exclusively and offers the product raw and in the form of recipes developed in partnership with Breton industrialists and a well-known Michelin-starred chef.

\section{Conclusion}

The ecological impact of aquatic invasive species is a growing concern for coastal zone management and conservation. The French Channel-Atlantic coasts make no exception, mainly due to international shipping and aquaculture practices. France even constitutes the European country most colonized by introduced species of macroalgae. Cost-benefit analysis of invasion management is not simple when several living resources economics are based upon the species invasiveness patterns (e.g. in shellfish and macrophyte aquaculture). Crassostrea gigas may be considered a pest in the Wadden Sea or in Australia where it outcompetes native oysters, but it supports a large fishery in France at the same time. Furthermore, there are numerous historical cases showing that initial "under control" does not mean permanent under control, even after several decades. Understanding interactions between human activities, ecosystem functioning and global changes is critical for further management options. New approaches should be developed to prevent any unintentional introduction as well as to limit sideeffects of on-going invasions. One cannot be optimistic when considering the on-going impacts of global change. Thus, the French Atlantic coast is facing at least three major environmental changes (P. Goulletquer, Ifremer, pers. com.): 1) mean annual seawater temperature is increasing regularly (ca. $1.5^{\circ} \mathrm{C}$ over the last 25 years); 2 ) there is a clear positive trend in the North Atlantic Oscillation; and 3) there is a drastic decline of freshwater inputs due to weather change and concomitant modifications in watershed activities (e.g. irrigation practices for agriculture). The marinization of estuaries leads to increased potential risks for new marine species invasions due to harbor proximity, while global warming favors the establishment of alien subtropical species (e.g. the harmful dinoflagellates of the genera Ostreopsis and Gambierdiscus in the Bay of Biscay). By definition, invasive species are capable to adapt to their new environment and they are best suited to face global changes. What about the native species which are not used to such environmental changes? Though global change is progressive, are all the species (native and invasive) going to adapt or are we going to observe homogenization of the flora and fauna at global scale?

\section{References}

[1] Coll, M., Piroddi, C., Steenbeek, J., Kaschner, K., Lasram, F.B.R., Aguzzi, J., Ballesteros, E., Bianchi, C.N., Corbera, J., Dailianis, T., Danovaro, R., Estrada, M., Froglia, C., Galil, B.S., Gasol, J.M., Gertwagen, R., Gil, J., Guihaumon, F., Kesner-Reyes, K., Kitsos, M.-S., Koukouras, A., Lampadario, N., Laxamana, E., Lopez de la Cuadra, C.M., Lotze, 
H.K., Martin, D., Mouillot, D., Oro, D., Raicevich, S., Rius-Barile, J., Saiz-Salinas, J.I., San Vicente, C., Somot, S., Templado, J., Turon, X., Vafidis, D., Villanueva, R. and Voultsiadou, E. (2010) The Biodiversity of the Mediterranean Sea: Estimates, Patterns, and Threats. PLoS ONE, 5, 1-36. http://dx.doi.org/10.1371/journal.pone.0011842

[2] Molnar,J.L., Gamboa, R.L., Revenga, C. and Spalding, M.D. (2008) Assessing the Global Threat of Invasive Species to Marine Biodiversity. Frontiers in Ecology and the Environnement, 6, 485-492. http://dx.doi.org/10.1890/070064

[3] Viard, F. and Comtet, T. (2009) Déferlantes d'invasions dans les milieux marins. Pour la Science, 65, 20-25.

[4] Katsanevakis, S., Wallentinus, I., Zenetos, A., Leppäkoski, E., Çinar, M.E., Oztürk, B., Grabowski, J.H., Golani, D. and Cardoso, A.C. (2014) Impacts of Invasive Alien Marine Species on Ecosystem Services and Biodiversity: A Pan-European Review. Aquatic Invasions, 9, 391-424. http://dx.doi.org/10.3391/ai.2014.9.4.01

[5] DAISIE (2009) Handbook on Alien Species in Europe. In: Drake, J.A., Ed., Invading Nature, Springer Series in Invasion Ecology, Vol. 3. Springer, Knoxville, 1-26.

[6] Boudouresque, C.F. and Verlaque, M. (2002) Biological Pollution in the Mediterranean Sea: Invasive versus Introduced Macrophytes. Marine Pollution Bulletin, 44, 32-38. http://dx.doi.org/10.1016/S0025-326X(01)00150-3

[7] Colautti, R.I., Grigorovich, I.A. and MacIsaac, H.J. (2006) Propagule Pressure: A Null Model for Biological Invasions. Biological Invasions, 8, 1023-1037. http://dx.doi.org/10.1007/s10530-005-3735-y

[8] Carlton, J.T. (1996) Pattern, Process, and Prediction in Marine Invasion Ecology. Biology Conservation, 78, 97-106. http://dx.doi.org/10.1016/0006-3207(96)00020-1

[9] Lockwood, J.L., Cassey, P. and Blackburn, T. (2005) The Role of Propagule Pressure in Explaining Species Invasions. TRENDS in Ecology and Evolution, 20, 223-228. http://dx.doi.org/10.1016/j.tree.2005.02.004

[10] Torchin, M.E., Lafferty, K.D. and Kuris, A.M. (2001) Release from Parasites as Natural Enemies: Increased Performance of a Globally Introduced Marine Crab. Biological Invasions, 3, 333-345. http://dx.doi.org/10.1023/A:1015855019360

[11] Colautti, R.I., Ricciardi, A., Grigorovich, I.A. and MacIssac, H.J. (2004) Is Invasion Success Explained by the Enemy Release Hypothesis? Ecology Letters, 7, 721-733. http://dx.doi.org/10.1111/j.1461-0248.2004.00616.x

[12] Dang, C., de Montaudouin, X., Bald, J., Jude, F., Raymond, N., Lanceleur, L., Paul-Pont, I. and Caill-Milly, N. (2009) Testing the Enemy Release Hypothesis: Trematode Parasites in the Non Indigenous Manila Clam Ruditapes philippinarum. Hydrobiologia, 630, 139-148. http://dx.doi.org/10.1007/s10750-009-9786-9

[13] Boudouresque, C.F. (2003) Les espèces introduites en milieu marin: Faut-il s'en inquiéter? Définitions, causes, effets biologiques et économiques. Proceedings Conférence du Comité du Vieux Marseille révisée, Marseille, 1-11.

[14] Nunes, A.L., Katsanevakis, S., Zenetos, A. and Cardoso, A.C. (2014) Gateways to Alien Invasions in the European seas. Aquatic Invasions, 9, 133-144. http://dx.doi.org/10.3391/ai.2014.9.2.02

[15] David, M. and Gollasch, S. (2008) EU Shipping in the Dawn of Managing the Ballast Water Issue. Marine Pollution Bulletin, 56, 1966-1972. http://dx.doi.org/10.1016/j.marpolbul.2008.09.027

[16] Goulletquer, P., Bachelet, G., Sauriau, P.G. and Noël, P. (2002) Open Atlantic Coast of Europe-A Century of Introduced Species into French Waters. In: Leppäkoski, E., Gollasch, S. and Olenin, S., Eds., Invasive Aquatic Species of Europe: Distribution, Impacts and Management, Kluwer Academic Publishers, Dordrecht, 276-290. http://dx.doi.org/10.1007/978-94-015-9956-6_30

[17] Quéro, J.-C., Du Buit, M.H. and Vayne, J.J. (1998) Les observations de poissons tropicaux et le réchauffement des eaux dans l'Atlantique européen. Oceanologica Acta, 21, 345-351. http://dx.doi.org/10.1016/S0399-1784(98)80021-2

[18] Le Treut, H. (2013) Les impacts du changement climatique en Aquitaine. Presses Universitaires de Bordeaux (PUB), Bordeaux.

[19] Nyberg, C.D. and Wallentinus, I. (2005) Can Species Traits Beused to Predict Marine Macroalgae Introductions? Biological Invasions, 7, 265-279. http://dx.doi.org/10.1007/s10530-004-0738-z

[20] Bazes, A. (2006) Recherche et valorisation de principes actifs antifouling isolés à partir de 3 macroalgues. Thèse de Doctorat de l’Université de Bretagne Sud (UBS), Vannes.

[21] Plouguerné, E. (2006) Étude écologique et chimique de deux algues introduites sur les côtes bretonnes, Grateloupia turuturu Yamada et Sargassum muticum (Yendo) Fensholt: Nouvelles ressources biologiques de composés à activité antifouling. Thèse de Doctorat de l’Université de Bretagne Occidentale (UBO), Brest.

[22] Le Lann, K. (2009) Etude de la biodiversité des Sargassaceae (Fucales, Phaeophyceae) en milieux tempéré et tropical: Ecologie, chimiotaxonomie et source de composés bioactifs. Thèse de Doctorat de l'Université de Bretagne Occidentale (UBO), sous le sceau de l’Université Européenne de Bretagne (UEB), Brest.

[23] Tanniou, A. (2014) Etude de la production de biomolécules d'intérêt (phlorotannins, pigments, lipides) par l'algue brune modèle Sargassum muticum par des approches combinées de profilage métabolique et d'écophysiologie. Thèse 
de doctorat de l’Université de Bretagne Occidentale, Brest.

[24] Simon-Colin, C. (2001) Applications de la résonance magnétique nucléaire à l'étude des solutés organiques majeurs potentiellement impliqués dans l'ajustement osmotique chez l'algue rouge invasive Grateloupia doryphora (Montagne) Howe. Thèse de Doctorat de l’Université de Bretagne Occidentale, Brest.

[25] Voisin, M. (2007) Les processus d'invasions biologiques en milieu côtier marin: Le cas de l'algue brune Undaria pinnatifida, cultivée et introduite à l'échelle mondiale. Thèse de Doctorat de l’Université Pierre \& Marie Curie, Paris.

[26] Voisin, M., Engel, C.R. and Viard, F. (2005) Differentialshuffling of native geneticdiversityacrossintroducedregions in a brownalga: Aquaculture vs. maritimetrafficeffects. PNAS, 102, 5432-5437. http://dx.doi.org/10.1073/pnas.0501754102

[27] Daguin, C., Voisin, M., Engel, C. and Viard, F. (2005) Microsatellites Isolation and Polymorphism in Introduced Populations of the Cultivated Seaweed Undaria pinnatifida (Phaeophyceae, Laminariales). Conservation Genetics, 6, 647-650. http://dx.doi.org/10.1007/s10592-005-9020-x

[28] Grulois, D., Leveque, L. and Viard, F. (2011) Mosaic Genetic Structure and Sustainable Establishment of the Invasive Kelp Undaria pinnatifida within a Bay (Bay of St. Malo, Brittany). Cahiers Biologie Marine, 52, 1-13.

[29] Grulois, D. (2010) Etude de la dispersion et du recrutement à différentes échelles spatiales chez Undaria pinnatifida, une macro-algue introduite le long des côtes bretonnes. Thèse de Doctorat de l’Université Pierre \& Marie Curie, Paris.

[30] Jacquin, A.G. (2008) Applications de biotechnologies végétales aux macroalgues marines: Développement de la micropropagation in vitro chez une Chlorophycée d'intérêt économique. Thèse de Doctorat de l'Université de Bretagne Occidentale (UBO), sous le sceau de l’Université Européenne de Bretagne (UEB), Brest.

[31] Rueness, J. (2005) Life History and Molecular Sequences of Gracilaria vermiculophylla (Gracilariales, Rhodophyta), a New Introduction to European Waters. Phycologia, 44, 120-128. http://dx.doi.org/10.2216/0031-8884(2005)44[120:LHAMSO]2.0.CO;2

[32] Thomsen, M., Staehr, P., Nyberg, C., Schwaerter, S., Krause-Jensen, D. and Silliman, B. (2007) Gracilaria vermiculophylla (Ohmi) Papenfuss, 1967 (Rhodophyta, Gracilariaceae) in Northern Europe, with Emphasis on Danish Conditions, and What to Expect in the Future. Aquatic invasions, 2, 83-94. http://dx.doi.org/10.3391/ai.2007.2.2.1

[33] Baumel, A., Ainouche, M.L., Misset, M.T., Gourret, J.P. and Bayer, R.J. (2003) Genetic Evidence for Hybridization between the Native Spartina maritima and the introduced Spartina alterniflora (Poaceae) in South-West France: Spartina $\times$ neyrautii Re-Examined. Plant Systematics and Evolution, 237, 87-97. http://dx.doi.org/10.1007/s00606-002-0251-8

[34] Querné, J. (2011) Invasion de Spartina alterniflora en rade de Brest: Comportement invasif et impact sur le cycle biogéochimique du silicium. Thèse de doctorat de l’Université de Bretagne Occidentale, Brest.

[35] Ainouche, M.L., Fortune, P.M., Salmon, A., Parisod, C., Grandbastien, M.A., Fukunaga, K., Ricou, M. and Misset, M.T. (2009) Hybridization, Polyploidy and Invasion: Lessons from Spartina (Poaceae). Biological Invasions, 11, 1159-1173. http://dx.doi.org/10.1007/s10530-008-9383-2

[36] Blanchard, M. (1997) Spread of the Slipper Limpet (Crepidula fornicata) in Europe. Current State and coNsequences. Scientia Marina, 61, 109-118.

[37] Thouzeau, G., Chauvaud, L., Grall, J. and Guérin, L. (2000) Do Biotic Interactions Control Pre-Recruitment and Growth of Pecten maximus (L.) in the Bay of Brest? Comptes-Rendus Académie des Sciences Paris, Sciences de la vie/Life sciences, 323, 815-825.

[38] Chauvaud, L., Jean, F., Ragueneau, O. and Thouzeau, G. (2000) Long-Term Variation of the Bay of Brest Ecosystem: Benthic-Pelagic Coupling Revisited. Marine Ecology Progress Series, 200, 35-48. http://dx.doi.org/10.3354/meps200035

[39] Guérin, L. (2004) La crépidule en rade de Brest: Un modèle biologique d’espèce introduite proliférante en réponse aux fluctuations de l'environnement. Thèse de doctorat de l’Université de Bretagne Occidentale, Brest.

[40] Blanchard, M. (2009) Recent Expansion of the Slipper Limpet Population (Crepidula fornicata) in the Bay of Mont Saint-Michel (Western Channel, France). Aquatic Living Resources, 22, 11-19. http://dx.doi.org/10.1051/alr/2009004

[41] Dupont, L., Richard, J., Paulet, Y.-M., Thouzeau, G. and Viard, F. (2006) Gregariousness and Protandry Promote Reproductive Insurance in the Invasive Gastropod Crepidula fornicata: Evidence from Assignment of Larval Paternity. MolecularEcology, 15, 3009-3021. http://dx.doi.org/10.1111/j.1365-294x.2006.02988.x

[42] Blanchard, M. (1995) Origine et état de la population de Crepidula fornicata (GastropodaProsobranchia) sur le littoral français. Haliotis, 24, 75-86.

[43] Richard, J., Huet, M., Thouzeau, G. and Paulet, Y.-M. (2006) Reproduction of the Invasive Slipper Limpet, Crepidula fornicata, in the Bay of Brest, France. Marine Biology, 149, 789-801. http://dx.doi.org/10.1007/s00227-005-0157-4

[44] Hoagland, K.E. (1986) Patterns of Encapsulation and Brooding in the Calyptraeidae (Prosobranchia: Mesogastropoda). 
American Malacological Bulletin, 4, 173-183.

[45] Lejart, M. (2009) Etude du processus invasif de Crassostrea gigas en Bretagne: Etat des lieux, dynamique et conséquences écologiques. Thèse de doctorat de l’Université de Bretagne Occidentale, Brest.

[46] Flassch, J.-P. and Leborgne, Y. (1992) Introduction in Europe, from 1972 to 1980, of the Japanese Manila clam (Tapes philippinarum) and the Effects on Aquaculture Production and Natural Settlement. ICES marine Science Symposium, 194, 92-96.

[47] Flye Sainte-Marie, J. (2008) Ecophysiology of Brown Ring Disease in the Manila clam, Ruditapes philippinarum, Experimental and Modelling Approaches. Ph.D. Dissertation, Vrije Universiteit, Amsterdam, and Université de Bretagne Occidentale, Brest.

[48] Mack, R.N., Simberloff, D., Lonsdale, W.M., Evans, H., Clout, M. and Bazzaz, F.A. (2000) Biotic Invasions: Causes, Epidemiology, Global Consequences, and Control. Ecological Applications, 10, 689-710. http://dx.doi.org/10.1890/1051-0761(2000)010[0689:BICEGC]2.0.CO;2

[49] Stachowitcz, J.J. and Byrnes, J.E. (2006) Species Diversity, Invasion Success, and Ecosystem Functioning: Disentangling the Influence of Resource Competition, Facilitation, and Extrinsic Factors. Marine Ecology Progress Series, 311, 251-262. http://dx.doi.org/10.3354/meps311251

[50] Arnott, D.L. and Vanni, M.J. (1996) Nitrogen and Phosphorus Recycling by the Zebra Mussel (Dreissena polymorpha) in the Western Basin of Lake Erie. Canadian Journal of Fisheries and Aquatic Sciences, 53, 646-659. http://dx.doi.org/10.1139/f95-214

[51] Ragueneau, O., Chauvaud, L., Leynaert, A., Thouzeau, G., Paulet, Y.-M., Bonnet, S., Lorrain, A., Grall, J., Corvaisier, R., Le Hir, M., Jean, F. and Clavier, J. (2002) Direct Evidence of a Biologically Active Coastal Silicate Pump: Ecological Implications. Limnology and Oceanography, 47, 1849-1854. http://dx.doi.org/10.4319/1o.2002.47.6.1849

[52] Ragueneau, O., Chauvaud, L., Moriceau, B., Leynaert, A., Thouzeau, G., Donval, A., Le Loc’h, F. and Jean, F. (2005) Biodeposition by an Invasive Suspension Feeder Impacts the Biogeochemical Cycle of Si in a Coastal Ecosystem (Bay of Brest, France). Biogeochemistry, 75, 19-41. http://dx.doi.org/10.1007/s10533-004-5677-3

[53] Martin, S., Thouzeau, G., Chauvaud, L., Jean, F., Guérin, L. and Clavier, J. (2006) Respiration, Calcification and Excretion of the Invasive Limpet, Crepidula fornicata L.: Implications for Carbon Carbonate and Nitrogen Fluxes. Limnology \& Oceanography, 51, 1996-2007. http://dx.doi.org/10.4319/lo.2006.51.5.1996

[54] Martin, S., Thouzeau, G., Richard, M., Chauvaud, L., Jean, F. and Clavier, J. (2007) Benthic Community Respiration in Areas Impacted by the Invasive Mollusk, Crepidula fornicata L. Marine Ecology Progress Series, 347, 51-60. http://dx.doi.org/10.3354/meps07000

[55] Laruelle, G., Regnier, P., Ragueneau, O., Kempa, M., Moriceau, B., Ni Longphuirt, S., Leynaert, A., Thouzeau, G. and Chauvaud, L. (2009) Benthic Pelagic Coupling and the Seasonal Silica Cycle in the Bay of Brest (France): New Insights from a Coupled Physical-Biological Model. Marine Ecology Progress Series, 385, 15-32. http://dx.doi.org/10.3354/meps07884

[56] Chauvaud, L., Thompson, J.K., Cloern, J.E. and Thouzeau, G. (2003) Clams as $\mathrm{CO}_{2}$ Generators: The Potamocorbula amurensis Example in San Francisco Bay. Limnology \& Oceanography, 48, 2086-2092. http://dx.doi.org/10.4319/lo.2003.48.6.2086

[57] Carlton, J.T., Thompson, J.K., Schemel, L.E. and Nichols, F.H. (1990) Remarkable Invasion of San Francisco Bay (California, USA) by the Asian Clam Potamocorbula amurensis. I. Introduction and Dispersal. Marine Ecology Progress Series, 66, 81-84. http://dx.doi.org/10.3354/meps066081

[58] Mills, E.L., Leach, J.H., Carlton, J.T. and Secor, C.L. (1993) Exotic Species in the Great Lakes: A History of Biotic Crises and Anthropogenic Introductions. Journal Great Lakes Research, 19, 1-54. http://dx.doi.org/10.1016/S0380-1330(93)71197-1

[59] Dame, R.F. (1996) Ecology of Marine Bivalves: An Ecosystem Approach. CRC Press, Boca Raton, FL. http://dx.doi.org/10.1201/9781420049787

[60] Middelburg, J.K., Duarte, C.M. and Gattuso, J.-P. (2005) Respiration in Coastal Benthic Communities. In: del Giorgio, P.A. and Williams, P.J.B., Eds., Respiration in Aquatic Ecosystems, Oxford University Press, Oxford, 206-224. http://dx.doi.org/10.1093/acprof:oso/9780198527084.003.0011

[61] Sousa, R., Gutiérrez, J.L. and Aldridge, D.C. (2009) Non-Indigenous Invasive Bivalves as Ecosystem Engineers. Biological Invasions, 11, 2367-2385. http://dx.doi.org/10.1007/s10530-009-9422-7

[62] Le Lann, K., Connan, S. and Stiger-Pouvreau, V. (2012) Phenology, TPC and Size-Fractioning Phenolics Variability in Temperate Sargassaceae (Phaeophyceae, Fucales) from Western Brittany: Native versus Introduced Species. Marine Environmental Research, 80, 1-11. http://dx.doi.org/10.1016/j.marenvres.2012.05.011

[63] Sparfel, L., Fichaut, B. and Suanez, S.(2005) Progression de la Spartine (Spartina alterniflora Loisel) en Rade de Brest (Finistère) entre 1952 et 2004 : De la mesure à la réponse gestionnaire. Norois, 196, 109-123. 
http://dx.doi.org/10.4000/norois.438

[64] Grosholz, E.D., Levin, L.A., Tyler, A.C. and Neira, C. (2009) Changes in Community Structure and Ecosystem Function Following Spartina alterniflora Invasion of Pacific Estuaries. In: Silliman, B.R., Grosholz, E.D. and Bertness, M.D., Eds., Human Impacts on Salt Marshes: A Global Perspective, University of California Press, Berkeley, 23-40.

[65] Gleason, M.L., Elmer, D.A., Pien, N.C. and Fisher, J.S. (1979) Effects of Stem Density upon Sediment Retention by Salt Marsh Cord Grass, Spartina alterniflora Loisel. Estuaries and Coasts, 2, 271-273. http://dx.doi.org/10.2307/1351574

[66] Lee, W.G. and Partridge, T.R. (1983) Rates of Spread of Spartina anglica and Sediment Accretion in the New River Estuary Invercargill, New Zealand. New Zealand Journal of Botany, 21, 231-236. http://dx.doi.org/10.1080/0028825X.1983.10428555

[67] Querné, J., Ragueneau, O. and Poupart, N. (2012) In Situ Biogenic Silica Variations in the Invasive Salt Marsh Plant, Spartina alterniflora: A Possible Link with Environmental Stress. Plant Soil, 352, 157-171. http://dx.doi.org/10.1007/s11104-011-0986-5

[68] Neira, C., Grosholz, E.D., Levin, L.A. and Blake, R. (2006) Mechanisms Generating Modification of Benthos Following Tidal Flat Invasion by a Spartina Hybrid. Ecological Applications, 16, 1391-1404. http://dx.doi.org/10.1890/1051-0761(2006)016[1391:MGMOBF]2.0.CO;2

[69] Quéré, E., Magnanon, S. and Annézo, N.(2010) Vingt ans de suivi et de conservation du Limonium humile Miller en rade de Brest. E.R.I.C.A. (Echos du Réseau pour l'Inventaire et la Cartographie Armoricaine), 23, 101-120.

[70] Brusati, E. and Grosholz, E.D. (2006) Native and Introduced Ecosystem Engineers Produce Contrasting Effects on Estuarine Infaunal Communities. Biological Invasions, 8, 683-695. http://dx.doi.org/10.1007/s10530-005-2889-y

[71] Hedge, P. and Kriwoken, L.K. (2000) Evidence for Effects of Spartina anglica Invasion on Benthic Macrofauna in Little Swanport Estuary, Tasmania. Austral Ecology, 25, 150-159. http://dx.doi.org/10.1046/j.1442-9993.2000.01016.x

[72] Daehler, C.C. and Strong, D.R. (1996) Status, Prediction and Prevention of Introduced Cordgrass Spartina spp. Invasions in Pacific Estuaries, USA. Biology Conservation, 78, 51-58. http://dx.doi.org/10.1016/0006-3207(96)00017-1

[73] Stenzel, L.E., Hickey, C.M., Kjelmyr, J.E. and Page, G.W. (2002) Abundance and Distribution of Shorebirds in the San Francisco Bay Area. Western Birds, 33, 69-98.

[74] Moulin, F.Y., Guizien, K., Thouzeau, G., Chapalain, G., Mülleners, K. and Bourg, C. (2007) Impact of an Invasive Species, Crepidula fornicata L., on the Hydrodynamic and Transport Properties of the Benthic Boundary Layer. Aquatic Living Resources, 20, 15-31. http://dx.doi.org/10.1051/alr:2007012

[75] Martin, S. (2005) Rôle d'une algue exploitée, le maërl, et d’une espèce invasive, la crépidule, sur les flux à l'interface eau-sédiment en rade de Brest. Thèse de doctorat de l’Université de Bretagne Occidentale, Brest.

[76] Chauvaud, L. (1998) La coquille Saint-Jacques en rade de Brest: Un modèle biologique d’étude des réponses de la faune benthique aux fluctuations de l'environnement. Thèse de doctorat de l’Université de Bretagne Occidentale, spécialité Océanologie Biologique, Brest.

[77] De Montaudouin, X. and Sauriau, P.-G. (1999) The Proliferating Gastropoda Crepidula fornicata May Stimulate Macrozoobenthic Diversity. Journal of the Marine Biological Association of the United Kingdom, 79, 1069-1077. http://dx.doi.org/10.1017/S0025315499001319

[78] De Montaudouin, X., Audemard, C. and Labourg, P.J. (1999) Does the Slipper Limpet (Crepidula fornicata) Impair Oyster Growth and Zoobenthos Biodiversity? A Revisited Hypothesis. Journal of Experimental Marine Biology and Ecology, 235, 105-124. http://dx.doi.org/10.1016/S0022-0981(98)00167-1

[79] Vallet, C., Dauvin, J.-C., Hamon, D. and Dupuy, C. (2001) Effect of the Introduced Common Slipper Shell on the Suprabenthic Biodiversity of the Subtidal Communities in the Bay of Saint-Brieuc. Conservation Biology, 15, 1686-1690. http://dx.doi.org/10.1046/j.1523-1739.2001.99295.x

[80] Decottignies, P., Beninger, P.G., Rincé, Y. and Riera, P. (2007) Trophic Interactions between Two Introduced Suspension-Feeders, Crepidula fornicata and Crassostrea gigas, Are Influenced by Seasonal Effects and Qualitative Selection Capacity. Journal of Experimental Marine Biology and Ecology, 342, 231-241. http://dx.doi.org/10.1016/j.jembe.2006.10.005

[81] Frésard, M. and Boncoeur, J. (2006) Costs and Benefits of Stock Enhancement and Biological Invasion Control: The Case of the Bay of Brest Scallop Fishery. Aquatic Living Resources, 19, 299-305. http://dx.doi.org/10.1051/alr:2006031

[82] Frésard, M. and Boncoeur, J. (2006) Controlling the Biological Invasion of a Commercial Fishery by a Space Competitor: A Bioeconomic Model with Reference to the Bay of St-Brieuc Scallop Fishery. Agricultural and Resource Economics Review, 35, 78-97. 
[83] Troost, K. (2010) Causes and Effects of a Highly Successful Marine Invasion: Case-Study of the Introduced Pacific Oyster Crassostrea gigas in Continental NW European Estuaries. Journal of Sea Research, 64, 145-165. http://dx.doi.org/10.1016/j.seares.2010.02.004

[84] Lejart, M. and Hily, C. (2011) Differential Response of Benthic Macrofauna to the Formation of Novel Oyster Reefs (Crassostrea gigas, Thunberg) on Soft and Rocky Substrate in the Intertidal of the Bay of Brest, France. Journal of Sea Research, 65, 84-93. http://dx.doi.org/10.1016/j.seares.2010.07.004

[85] Lejart, M., Clavier, J., Chauvaud, L. and Hily, C. (2012) Respiration and Calcification of Crassostrea gigas: Contribution of an Intertidal Invasive Species to Coastal Ecosystem $\mathrm{CO}_{2}$ Fluxes. Estuaries and Coasts, 35, 622-632. http://dx.doi.org/10.1007/s12237-011-9462-y

[86] Hily, C., Grall, J., Chauvaud, L., Lejart, M. and Clavier, J. (2013) $\mathrm{CO}_{2}$ Generation by Calcified Invertebrates along Rocky Shores of Brittany, France. Marine and Freshwater Research, 64, 91-101. http://dx.doi.org/10.1071/MF12146

[87] Scourzic, T., Loyen, M., Fabre, E., Tessier, A., Dalias, N., Trut, G., Maurer, D. and Simonnet, B. (2011) Evaluation du stock d'huîtres sauvages et en élevage dans le Bassin d'Arcachon. Contrat Agence des Aires Marines Protégées \& OCEANIDE, Fr: 70.

[88] Anderson, L.W.J. (2005) California’s Reaction to Caulerpa taxifolia: A Model for Invasive Species Rapid Response. Biological Invasions, 7, 1003-1016. http://dx.doi.org/10.1007/s10530-004-3123-z

[89] Perez, R. (1972) Opportunité de l'implantation de l'algue Macrocystis pyrifera sur les côtes bretonnes. Science et Pêche, Bulletin de l'Institut des Pêches maritimes, 216, 1-9.

[90] Perez, R., Couespel Du Mesnil, J., Colin, Y., Le Fur, L. and Didou, H. (1973) Etude sur l'opportunité d’introduire l'algue Macrocystis sur le littoral français. Revue des Travaux de l'Institut des Pêches maritimes, 37, 307-361.

[91] Meisnez, A. (2007) Methods for Identifying and Tracking Seaweed Invasions. Botanica Marina, 50, 373-384.

[92] de Montaudouin, X., Labarraque, D., Giraud, K. and Bachelet, G. (2001) Why Does the Introduced Gastropod Crepidula fornicata Fail to Invade Arcachon Bay (France)? Journal of the Marine Biological Association of the United Kingdom, 81, 97-104. http://dx.doi.org/10.1017/S0025315401003447

[93] Miossec, L., Le Deuff, R.-M. and Goulletquer, P. (2009) Alien Species Alert: Crassostrea gigas (Pacific Oyster). ICES Cooperative Research Report, 299, 1-42.

[94] Bazes, A., Silkina, A., Douzenel, P., Faÿ, F., Kervarec, N., Morin, D., Bergé, J.-P. and Bourgougnon, N. (2009) Investigation of the Antifouling Constituents from the Brown Alga Sargassum muticum (Yendo) Fensholt. Journal of Applied Phycology, 21, 395-403. http://dx.doi.org/10.1007/s10811-008-9382-9

[95] Plouguerné, E., Hellio, C., Deslandes, E., Véron, B., Bremer, G. and Stiger-Pouvreau, V. (2008) Anti-Microfouling Activities of Extracts of Two Invasive Algae: Grateloupia turuturu and Sargassum muticum. Botanica Marina, 51, 202-208. http://dx.doi.org/10.1515/BOT.2008.026

[96] Plouguerné, E., Georgantea, P., Ioannou, E., Vagias, C., Roussis, V., Hellio, C., Kraffe, E. and Stiger-Pouvreau, V. (2010) Anti-Microfouling Activity of Lipidic Metabolites from the Invasive Brown Alga Sargassum muticum (Yendo) Fensholt. Marine Biotechnology, 12, 52-61. http://dx.doi.org/10.1007/s10126-009-9199-9

[97] Silkina, A., Bazes, A., Mouget, J.-L. and Bourgougnon, N. (2012) Comparative Efficiency of Macroalgal Extracts and Booster Biocides as Antifouling Agents to Control Growth of Three Diatom Species. Marine Pollution Bulletin, 64, 2039-2046. http://dx.doi.org/10.1016/j.marpolbul.2012.06.028

[98] Le Lann, K., Jégou, C. and Stiger-Pouvreau, V. (2008) Impact of Different Conditioning Treatments on Total Phenolic Content and Antioxidant Activities in Two Sargassacean Species: Comparison of the Frondose Sargassum muticum (Yendo) Fensholt and the Cylindrical Bifurcaria bifurcata R. Ross. Phycology Research, 56, 238-245. http://dx.doi.org/10.1111/j.1440-1835.2008.00505.x

[99] Hardouin, K., Burlot, A.-S., Umami, A., Tanniou, A., Stiger-Pouvreau, V., Widowati, I., Bedoux, G. and Bourgougnon, N. (2013) Biochemical and Antiviral Activities of Enzymatic Hydrolysates from Different Invasive French Seaweeds. Journal of Applied Phycology, 26, 1029-1042. http://dx.doi.org/10.1007/s10811-013-0201-6

[100] Stiger-Pouvreau, V., Jégou, C., Cérantola, S., Guérard, F. and Le Lann, K. (2014) Phlorotannins in Sargassaceae Species from Brittany (France): Interesting Molecules for Ecophysiological and Valorisation Purposes. Advances in Botanical Research, 71, 379-412. http://dx.doi.org/10.1016/B978-0-12-408062-1.00013-5

[101] Tanniou, A., Vandanjon, L., Incera, M., Serrano Léon, E., Husa, V., Le Grand, J., Nicolas, J-L., Poupart, N., Kervarec, N., Engelen, A., Walsh, R., Guérard, F., Bourgougnon, N. and Stiger-Pouvreau, V. (2013) Assessment of the Spatial Variability of Phenolic Contents and Associated Bioactivities in the Invasive Alga Sargassum muticum Sampled along Its European Range from Norway to Portugal. Journal of Applied Phycology, 26, 1215-1230. http://dx.doi.org/10.1007/s10811-013-0198-x

[102] Tanniou, A., Serrano Léon, E., Vandanjon, L., Ibanez, E., Mendiola, J.A., Cérantola, S., Kervarec, N., Barre, S., Marchal, L. and Stiger-Pouvreau, V. (2013) Green Improved Processes to Extract Bioactive Phenolic Compounds from 
Brown Macroalgae Using Sargassum muticum as Model. Talanta, 104, 44-52. http://dx.doi.org/10.1016/j.talanta.2012.10.088

[103] Plouguerné, E., Kikuchi, H., Oshima, Y., Deslandes, E. and Stiger-Pouvreau, V. (2006) Isolation of Cholest-5-en-3-ol Formate from the Red Alga Grateloupia turuturu Yamada and Its Chemotaxonomic Significance. Biochemical Systematics and Ecology, 34, 714-717. http://dx.doi.org/10.1016/j.bse.2006.04.003

[104] Garcia-Bueno, N., Decottignies, P., Turpin, V., Dumay, J., Paillard, C., Stiger-Pouvreau, V., Kervarec, N., Pouchus, Y-F., Aitor Marin-Atucha, A. and Fleurence, J. (2014) Seasonal Antibacterial Activity of Two Red Seaweeds, Palmaria palmata and Grateloupia turuturu, on European Abalone Pathogen Vibrio harveyi. Aquatic Living Resources, 27, 83-89. http://dx.doi.org/10.1051/alr/2014009

[105] Denis, C. (2009) Etudes des caractéristiques biochimiques de l'algue Grateloupia turuturuet application de l'hydrolyse enzymatique comme procédé d'obtention d'un pigment d’intérêt biologique et économique la R-Phycoérytrine. Thèse de Doctorat de l'Université de Nantes, Nantes.

[106] Denis, C., Massé, A., Fleurence, J. and Jaouen, P. (2009) Concentration and Pre-Purification with Ultrafiltration of a R-Phycoerythrin Solution Extracted from the Macroalgae Grateloupia turuturu: Process Definition and Up-Scaling. Separation and Purification Technology, 69, 37-42. http://dx.doi.org/10.1016/j.seppur.2009.06.017

[107] Denis, C., Morançais, M., Lia, M., Deniaud, E., Gaudin, P., Wielgosz-Collin, G., Barnathan, G., Jaouen, P. and Fleurence, J. (2010) Study of the Chemical Composition of Edible Red Macroalgae Grateloupia turuturu from Brittany (France). Food Chemistry, 119, 913-917. http://dx.doi.org/10.1016/j.foodchem.2009.07.047 